\title{
Ewa OSEK*
}

\section{HYMNY PROKLOSA: FILOZOFIA I KULT}

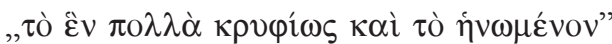 \\ „Jedność w tajemny sposób staje się wielością, a potem znowu jednością"1.
}

\section{WSTĘP}

Spośród licznych hymnów późnego neoplatonika Proklosa (412-485) tradycja przechowała zaledwie siedem², których polski przekład Czytelnik znajdzie w dalszej części niniejszego artykułu. Być może kompozycją tegoż autora jest także homerycki hymn ósmy do Aresa i Hymn do Boga przypisywany Grzegorzowi z Nazjanzu ${ }^{3}$. Poezje te, mające ewidentny związek z dawnym kultem pogańskim, budziły żywe zainteresowanie w kręgu odrodzonej we Florencji Akademii Platońskiej (1439-1492). Fascynował się nimi bizantyński neoplatonik i neopoganin Gemistos Plethon (1355-1454), znany Europie zachodniej z otwartych wykładów we Florencji w 1438 roku. Czytywał je i tłumaczył na język łaciński Marsilio Ficino (1433-1499), lecz z obawy przed inkwizycją nie zdecydował się na ich publikację ${ }^{4}$ Obecnie dysponujemy szeregiem przekładów na języki nowożytne z wyjątkiem polskiego, a także wachlarzem wnikliwych opracowań,

* Dr Ewa Osek - adiunkt w Katedrze Języka i Literatury Greckiej Późnego Antyku w Instytucie Filologii Klasycznej na Wydziale Nauk Humanistycznych Katolickiego Uniwersytetu Lubelskiego Jana Pawła II; e-mail: ewaosek@wp.pl.

${ }^{1}$ Proclus, Theologia Platonica III 14, ed. H.D. Saffrey - L.G. Westerink: Proclus, Théologie platonicienne, I-VI, Paris 1968-1997, Les Belles Lettres, tutaj: III 52, 7-8 (poszczególne cyfry oznaczają tom, stronę i wiersze w cytowanej edycji). Jeśli nie zaznaczono inaczej, przekłady pochodzą od autorki [E.O.].

${ }^{2}$ Por. Proclus, Hymni, ed. E. Vogt: Procli hymni accedunt hymnorum fragmenta, epigrammata, scholia, fontium et locorum similium apparatus, indices, Wiesbaden 1957, Harrassowitz.

${ }^{3}$ Por. Gregorius Nazianzenus, Carmina I 1, 29, PG 37, 507A-508A = Proclus, Eclogae e Proclo de philosophia Chaldaica, accedit hymnus in deum Platonicus, ed. A. Iahnius, Halis Saxonum 1891, Pfeffer, 49, zob. także M.L. West, The Eighth Homeric Hymn and Proclus, CQ 20 (1970) 300-304; M. Sicherl, Ein Neuplatonischer Hymnus unter den Gedichten Gregors von Nazianz, w: Gonimos: Neoplatonic and Byzantine studies presented to Leendert G. Westerink at 75, ed. J. Duffy - J. Peradotto, Buffalo 1988, Arethusa, 61-83.

${ }^{4}$ Por. I. Klutstein, Marsilio Ficino et la théologie ancienne: oracles chaldaïques, hymnes orphiques, hymnes de Proclus, Firenze 1987, Olschki. 
z których najbardziej cenionym jest monumentalne studium holenderskiego uczonego Robberta M. Van den Berga .

Przed przystąpieniem do prezentacji tych utworów należy postawić następujące pytania badawcze: (1) do jakich wzorców literackich nawiązał autor, (2) jaki był cel kompozycji hymnów i (3) skąd pochodzą bogowie - Helios, Afrodyta, Muzy, Matka Bogów, Hekate, Janus i Atena - wymieniani jako adresaci. Odpowiedź na powyższe pytania nie jest prosta, mimo że trudno narzekać na brak źródeł. Sam Proklos, diadoch Akademii Platońskiej przez prawie półwiecze (437-485), pisywał traktaty teologiczne, a w swoich filozoficznych pismach uwielbiał dywagować na tematy religijne, a nawet cytować spore fragmenty autentycznych tekstów kultowych. Ponadto zachowała się w całości obszerna hagiografia Proklos albo o szczęściu pióra Marinosa z Neapolis ${ }^{6}$ w Samarii, następcy Proklosa w latach 485-490, oraz spore fragmenty $\dot{Z} y$ wota Izydora lub Historii filozofii, skomponowanego przez Damascjusza ${ }^{7}$, ostatniego diadocha Akademii w latach 515-529, czyli bezpośrednio przed zamknięciem tej instytucji przez cesarza Justyniana.

1. Inspiracje. Pytanie o wzorce literackie tak oczytanego autora nie należy do łatwych. Trzeba bowiem brać pod uwagę nie tylko pieśni znane szerokiej publiczności, takie jak Hymny homeryckie ${ }^{8}$, lecz także bardziej ezoteryczne teksty, recytowane w zamkniętych kręgach ostatnich wyznawców kultów pogańskich i filozofów neoplatońskich. Mam na myśli przede wszystkim utwory z II wieku po Chr. i wcześniejsze: heksametryczne Rapsodie orfickie ${ }^{9}$, orficki hymn do Heliosa ${ }^{10}$, inne hymny orfickie, niestety źle zachowane ${ }^{11}$, Hymny orfickie towarzyszące ofiarom dla siedemdziesięciu bogów podczas inicjacji w misteria orfickie ${ }^{12}$, pieśni Mezomedesa z Krety w bardziej skomplikowanych miarach metrycznych i przeznaczone do śpiewu z akompaniamentem

\footnotetext{
${ }^{5}$ Por. R.M. Van den Berg, Proclus' Hymns, Leiden 2001, Brill.

${ }^{6}$ Por. Marinus Neapolitanus, Vita Procli, ed. R. Masullo: Marino di Neapoli, Vita di Proclo, Napoli 1985, Auria.

${ }^{7}$ Por. Damascius, Vita Isidori, ed. C. Zintzen: Damascii Vitae Isidori reliquiae, Hildesheim 1967, Olms.

${ }^{8}$ Por. Hymni Homerici, ed. H.G. Evelyn-White, The Homeric Hymns and Homerica, w: Hesiod, Cambridge MA 1914, Loeb, 285-463, tłum. W. Appel: Hymny homeryckie, Warszawa 2001, Algo.

${ }^{9}$ Wszystkie teksty orfickie cytuję według najnowszego wydania: Poetae epici Graeci, testimonia et fragmenta, pars II, fasc. 1-2: Orphicorum et Orphicis similium testimonia et fragmenta (= OF), ed. A. Bernabé, München 2004-2005, Saur.

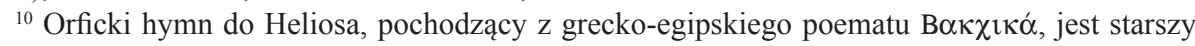
niż II wiek, por. OF 538-545.

${ }^{11}$ Por. OF 680-705.

${ }^{12}$ Hymni Orphici (= OH) cytuję według wydania: Inni orfici, ed. G. Ricciardelli, Milano 2000, tłum. E. Żybert: Hymny orfickie, Wrocław 2012, Atut. Przy 78 spośród 87 z nich manuskrypty podają rodzaje ofiar: kadzidło, wonności, styraks, manna i libanomanna (być może kadzidlany granulat), mirra, szafran, potpourri (być może egipska mieszanka o nazwie $k y f i$ ), libacje z mleka, ziarna z wyjątkiem bobu, mak, zapalona pochodnia.
} 
kitary $^{13}$, oraz Wyrocznie chaldejskie w heksametrach - pseudoepigraf Juliana Teurga, chętnie komentowany w szkole neoplatońskiej od czasów Porfiriusza ${ }^{14}$. Duży wpływ na Proklosa wywarli dwaj wcześniejsi neoplatonicy o talentach literackich. Julian Apostata w 362 r. skomponował hymny prozą ku czci Heliosa i Matki Bogów ${ }^{15}$, oraz mit o Heliosie w efektownej prozie azjańskiej ${ }^{16}$. Synezjusz z Cyreny - w jednej osobie znajomy Hypatii z Aleksandrii i biskup Ptolemais w Libii (410-414) - genialnie połączył chrześcijańską teologię trynitarną z Wyroczniami chaldejskimi w swoich Hymnach metrycz$n y c h^{17}$, ułożonych w dialekcie doryckim i różnych miarach. Współczesny Proklosowi poeta Nonnos z Panopolis wcielił do swojego gigantycznego eposu Dionysiaka (48 ksiąg) ${ }^{18}$ hymn do Heraklesa Astrochitona ${ }^{19}$, którego treść, a zwłaszcza metrum, tzw. heksametr nonniański, są kompatybilne z Hymnem 1. Nie powinno się pomijać popularnych w późnym antyku hymnów magicznych i kultowo-terapeutycznych, o których pewne wyobrażenie dają papirusy magiczne z Egiptu ${ }^{20}$ oraz inskrypcje z Epidauros ${ }^{21}$ i Aten ${ }^{22}$ - wykute w kamieniu hymny na cześć bogów-uzdrowicieli z informacjami o godzinie, o której dany pean miał być śpiewany przez chór świątynny ${ }^{23}$.

Spośród możliwych wzorców literackich Robbert M. Van Den Berg preferuje Wyrocznie chaldejskie, uwzględnia też, aczkolwiek w mniejszym stop-

${ }^{13}$ Por. Mesomedes, Fragmenta. Cytuję Mezomedesa według wydania: Documents of Ancient Greek Music: The Extant Melodies and Fragments (= DAGM), ed. E. Pöhlmann - M.L. West, Oxford 2001, Clarendon, 92-116.

${ }^{14}$ Oracula Chaldaica (= OC) mają, jak dotąd, dwa wydania, w których zastosowano identyczną numerację fragmentów: éd. É. des Places: Oracles chaldaïques, avec un choix de commentaires anciens, Paris $1996^{3}$, Les Belles Lettres; ed. R.D. Majercik: Julianus the Theurgist: The Chaldean Oracles, Leiden 1989, Brill.

${ }^{15}$ Por. Julianus, Orationes 4(11) i 5(8), ed. W.C. Wright: The Works of the Emperor Julian, I, London - New York 1913, Loeb, 353-504.

${ }^{16}$ Por. Julianus, Oratio 7, 22, ed. W.C. Wright, s. 130-149, thum. E. Osek: Juliana Apostaty mit o Heliosie, VoxP 30 (2010) nr 55, 477-498.

${ }^{17}$ Por. Synesius Cyrenensis, Hymni, éd. C. Lacombrade: Synésios de Cyrène, Hymnes, I, Paris 1978, Les Belles Lettres.

${ }^{18}$ Por. Nonnus Panopolitanus, Dionysiaca, ed. W.H.D. Rouse, I-III, Cambridge MA 1940, Loeb.

${ }^{19}$ Por. tamże 40, 366-411, ed. Rouse, III, s. 180-183.

${ }^{20}$ Por. Papyri Graecae Magicae (= PGM), I-II, ed. K. Preisendanz - A. Henrichs, Stuttgart 1973-1974², Teubner.

${ }^{21}$ Por. Inscriptiones Graecae IV ${ }^{2}$ : Inscriptiones Epidauri, ed. F. Hiller von Gaertringen, Berlin 1929, Berlin-Brandenburgische Akademie der Wissenschaften.

${ }^{22}$ Por. Inscriptiones Graecae $\mathrm{III}^{1}$ : Inscriptiones Atticae aetatis Romanae, ed. G. Dittenberger, I, Berlin 1878, Berlin-Brandenburgische Akademie der Wissenschaften.

${ }^{23}$ Hymn do Hygiei (Inscriptiones Graecae IV ${ }^{2} 1$ 1, 132) opatrzony jest uwagą: „o pierwszej godzinie” (tj. o szóstej rano), hymn do Pallady (Inscriptiones Graecae IV ${ }^{2} 1,134$ ) otrzymał adnotację „o trzeciej godzinie” (tj. dziewiątej rano); por. Aelius Aristides, Hieroi logoi 1, 30, ed. B. Keil: Aelii Aristidis Smyrnaei quae supersunt omnia, II, Berlin 1898, Weidmann, 383: „Śniło mi się, że byłem w Świątyni Asklepiosa o świcie, zaszedłszy tam prosto z drogi. Ucieszyłem się, że jest już otwarta. Chłopcy śpiewali ten stary hymn, który zaczyna się tak: Wysławiam Zeusa najwyższego...”. 
niu, Hymny homeryckie, Hymny orfickie i Juliana Apostatę ${ }^{24}$. Poza tym uczony ten minimalizuje bądź marginalizuje wpływ Rapsodii orfickich i innych fragmentarycznie zachowanych poezji orfickich, hymnów magicznych i Nonnosa, wyklucza Synezjusza z Cyreny z powodu jego konwersji na chrześcijaństwo i przynależności do innego niż Proklos odłamu neoplatonizmu (choć, nawiasem mówiąc, Synezjusz korzystał z literatury chaldejskiej znacznie więcej niż Proklos w Hymnach), nieomal zapomina o istnieniu Mezomedesa i całkowicie ignoruje epigraficzne hymny z Epidauros, tudzież wszelkie inne inskrypcje. W rezultacie ogranicza się do jednostronnego ukazania zależności Hymnów Proklosa od Wyroczni chaldejskich i związanych z nimi komentarzy neoplatońskich. Wykażę niżej, że Van den Berg stawia na „niewłaściwego konia”.

2. Hymny kultowe. Nie ulega wątpliwości, że hymny Proklosa miały służyć określonym celom kultowym. Robbert M. Van den Berg argumentuje, że była to teurgia, czyli chaldejska magia, z którą Proklos zapoznał się za pośrednictwem diadocha Plutarcha z Aten (350-432) i jego córki, Asklepigenei $^{25}$. Filozof sam został teurgiem, a Wyrocznie chaldejskie stały się obsesją jego życia ${ }^{26}$.

Niejakie wyobrażenie o tym, czym właściwie była teurgia, mogą dać $W y$ rocznie chaldejskie, zachowane we fragmentach dzięki neoplatonikom, którzy doszukiwali się w nich głębokiej duchowej treści. Tekst Wyroczni miał w ręku jeszcze Michał Psellos (1018-1078) i napisał doń komentarz ${ }^{27}$, potem utwór zaginął. Jak można wnosić z fragmentów, teurgia polegała na przywołaniu Hekate, jednej z triady najwyższych bogów chaldejskich, na pomoc w odprawianiu czarów ${ }^{28}$, a także na podporządkowaniu sobie demonów eteru i wiatru ${ }^{29}$ oraz psów ziemi, wody i powietrza ${ }^{30}$. Wykonywanie profesji teurga wymagało serii rytuałów oczyszczających, albowiem psy mogły być groźne dla nieczystych ${ }^{31}$.

Znamienne było to, że teurg wzywał Święty Ogień Hekate w peanach i mistycznych hymnach, śpiewanych w uroczystej ciszy ${ }^{32}$, podczas gdy demony ściągał bezceremonialnie na ziemię za pomocą zaklęć, figurek, kamieni, krążków i kul magicznych ${ }^{33}$. Najwyższy z chaldejskiej trójcy, Ojciec, był czczony

\footnotetext{
${ }^{24}$ Por. Van den Berg, Proclus' Hymns, s. 31-33.

${ }^{25}$ Por. tamże, s. 66-111.

${ }^{26}$ Por. Marinus Neapolitanus, Vita Procli 26-28, ed. Masullo, s. 81-85.

${ }^{27}$ Por. Michael Psellus, Expositio in Oracula Chaldaica, PG 122, 1123A-1149A.

${ }^{28}$ Por. OC 2, 35, 49, 72, 131-133 i 147-148, ed. Majercik, s. 48, 60, 68, 78, 98 i 104.

${ }^{29}$ Por. OC 146, 149-150 i 223, ed. Majercik, s. 104, 106 i 136.

${ }^{30}$ Por. OC 90-91, ed. Majercik, s. 84.

${ }^{31}$ Por. OC 116 i 135, ed. Majercik, s. 92 i 100.

${ }^{32}$ Por. OC 131 i 219, ed. Majercik, s. 98 i 134; zob. też Synesius Cyrenensis, Hymnus 1(3), 8287, éd. C. Lacombrade, Synésios de Cyrène, I: Hymnes, Paris 1978, Les Belles Lettres, 47: „Niech milczą zakątki świata, gdy my wznosimy święty hymn, niech schowa się pod ziemię wężów rój”.

${ }^{33}$ Por. OC 206 i 223-224, ed. Majercik, s. 126 i 136.
} 
jeszcze inaczej: hymnem śpiewanym w milczeniu, ofiarą serca. Pięknym przykładem takiego „milczącego” hymnu do Ojca - Pierwszego Ognia jest jeden z tekstów Proklosa skomponowany w artystycznej prozie azjańskiej:

„Wznieśmy hymn do Boga.
Porzućmy płynną materię.
Idźmy do prawdziwego celu:
Upodobnienia do Niego.
Poznajmy Pana.
Pokochajmy Ojca.
Bądźmy posłuszni wezwaniu.
Biegnijmy do żaru.
Unikajmy zimna.
Stańmy się ogniem.
Idźmy przez ogień.
Droga powrotu jest łatwa.
Ojciec wskazuje drogę.
Ojciec otwiera drogi ognia,
Byśmy nie popłynęli strumieniem Lete"34.

Wiadomo od Marinosa, że Proklos praktykował chaldejskie oczyszczenia, miał objawienia bogini Hekate, wróżył z magicznej kuli $\sigma \tau \rho o ́ \varphi \alpha \lambda o s$, sprowadzał deszcz za pomocą magicznego krążka î́ $\xi^{35}$, produkował amulety ochronne przeciw trzęsieniu ziemi i trzy razy każdego dnia oddawał pokłon słońcu, gdy wschodziło, było w zenicie i zachodziło ${ }^{36}$. Wróćmy teraz do tezy Van den Berga. Czy zachowane hymny Proklosa mogły być hymnami teurgicznymi? Gdyby tak było, ich adresatką powinna być bogini Hekate, zwana

${ }^{34}$ Proclus, Eclogae e Proclo de philosophia Chaldaica 2, ed. Iahnius, s. 2. W tym samym miejscu Proklos pisze: „Hymn do Ojca to nie układ słów ani czynów dokonanie. Ojciec, sam niezniszczalny, nie przyjmuje hymnów zniszczalnych. Nie liczmy na to, że burza pustosłowia czy pozór czynów przez sztukę upiększonych przekona władcę słów prawdziwych. Bóg kocha harmonię, nie potrzebuje pozorów piękna"; zob. także: H. Lewy, Chaldean Oracles and Theurgy: Mysticism Magic and Platonism in the Later Roman Empire, Paris $1978^{3}$ (Nouv. éd. par M. Tardieu), Études Augustiniennes, 491-493.

${ }^{35} \mathrm{Na}$ temat magicznych akcesoriów por. R.D. Majercik, Introduction, w: Julianus the Theurgist, The Chaldean Oracles, s. xxix-xxx; zob. także Michael Psellus, Expositio in Oracula Chaldaica, PG

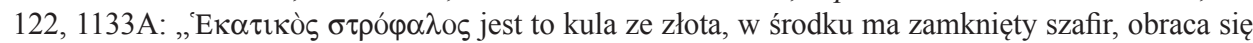
na rzemieniu z byczej skóry, są na niej wygrawerowane inskrypcje. Teurgowie posługują się nią pod-

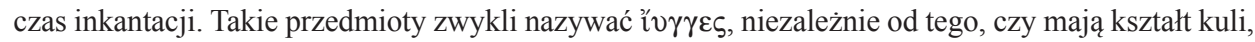
trójkąta czy jakikolwiek inny. Obracając się, wydają nieartykułowane dźwięki: zwierzęce, chichoty albo świsty. Wyrocznie chaldejskie nauczają, że już sam ruch kuli ma taką moc, że dokonuje inicjacji. Kula nosi nazwę Hekate, ponieważ jest poświęcona tej bogini”; por. OC 206, ed. Majercik, s. 127.

${ }^{36}$ Por. Marinus Neapolitanus, Vita Procli 18, 22 i 28, ed. Masullo, s. 75, 79 i 84; zob. też Synesius Cyrenensis, Hymnus 1(3), 23-28, ed. Lacombrade, s. 7: „Noc przynosi Ci mnie, aojda, Panie. Dla Ciebie dzienne, dla Ciebie ranne, dla Ciebie wieczorne hymny wznoszę"; tamże 2(4), 1-6, ed. Lacombrade, s. 61: „Do Ciebie śpiewam, gdy dzień się zaczyna, gdy jest w połowie, gdy się kończy, o świętym świcie, o świętym zmierzchu”. 
inaczej Kwiatem Umysłu, Kwiatem Ognia, Źródłem, Łonem, Centrum, Reą, Matką Bogów i Duszą Świata, a jeśli nie wyłącznie ona, to cała trójca chaldejska: Ojciec, Eon i Kwiat Umysłu ${ }^{37}$. Jedyny hymn Proklosa, który spośród siedmiu może z pewnym zastrzeżeniami uchodzić za chaldejski, to Hymn 6 do Hekate i Janusa. Nie wchodzą w grę hymny do bogów niższej niż oni kategorii: Hymn 1 do Heliosa, identyfikowanego z Attysem i Adonisem, Hymn 2 do zrodzonej z piany Afrodyty, Hymn 3 do Muz, potomkiń Apollona, Hymn 4 do bogów anagogicznych, Hymn 5 do Afrodyty z Licji i Hymn 7 do Ateny z Akropolu. Żaden z tych hymnów nie znalazłby zastosowania w rycie chaldejskim. Co innego hymny Synezjusza z Cyreny, z których większość, poza dwoma czy trzema, jest bardziej chaldejska od samych Wyroczni $i^{38}$.

Skoro hymny Proklosa nie są teurgiczne, to jakie? Odpowiedź na to pytanie znajduje się u Marinosa. Otóż Proklos, zgodnie z ówczesną neoplatońską modą $^{39}$, kultywował nie tylko teurgię, lecz także inne religie ginącego pogaństwa i celebrował w Akademii wszystkie święta wszystkich ludów. „Ten najpobożniejszy mąż zwykł mawiać - pisze Marinos - że filozof ma być hierofantą nie jednego miasta czy jednej religii, lecz całego świata" ${ }^{40}$. Zatem skrupulatnie obchodził święta różnych religii, przestrzegał postów i nakazanych ablucji, niezależnie od tego czy były one chaldejskie, orfickie czy wymagane przez kult Asklepiosa ${ }^{41}$. Próbował restytuować wyrocznię, wieszcząc z trójnogu magicznego i układając o sobie proroctwa w heksametrach ${ }^{42}$. Oprócz bogów chaldejskich czcił panteon grecki, a ponadto bogów małoazjatyckich, rzymskich, egipskich, syryjskich i arabskich. Na liście szczególnie czczonych bóstw znaleźli się Apollon z Ksantos w Licjii ${ }^{43}$, Atena Poliuchos z Konstantynopola $^{44}$, Matka Bogów ${ }^{45}$, Izyda ${ }^{46}$, Hekate $^{47}$, Telesforos ${ }^{48}$, Marnas ${ }^{49}$,

${ }^{37}$ Por. OC 49, ed. Majercik, s. 68.

${ }^{38}$ Por. W. Theiler, Die chaldäischen Orakel und die Hymnen des Synesios, Schriften der Königsberger Gelehrten Gesellschaft: Geitsteswissenschaftliche Klasse 18, Halle 1942, 1-41 (repr. W. Theiler, Forschungen zum Neuplatonismus, Berlin 1966, Gruyter, 252-301).

${ }^{39}$ Por. Damascius, Vita Isidori fr. 163, ed. Zintzen, s. 137: „Stąd też życie Heraiskosa do takiej doszło świętości, że dusza jego mieszkała zawsze w jakimś adytonie czy telesterionie, bo wtajemniczał się nie tylko w rodzime egipskie misteria, lecz także innych narodów, jeśli gdzieś jeszcze jakieś pozostały. I stał się Heraiskos bachusem, jak zalecił mu sen"; zob. też tamże fr. 100, ed. Zintzen, s. 75.

${ }^{40}$ Marinus Neapolitanus, Vita Procli 19, ed. Masullo, s. 76.

${ }^{41}$ Por. tamże 18, ed. Masullo, s. 75.

${ }^{42}$ Por. tamże 28, ed. Masullo, s. 84-85.

${ }^{43}$ Por. tamże 6, ed. Masullo, s. 63.

${ }^{44}$ Por. tamże 6, ed. Masullo, s. 63.

${ }^{45}$ Por. tamże 19 i 33, ed. Masullo, s. 75 i 89.

${ }^{46}$ Por. tamże 19, ed. Masullo, s. 76.

${ }^{47}$ Por. tamże 28, ed. Masullo, s. 84.

${ }^{48}$ Por. tamże 7, ed. Masullo, s. 64.

${ }^{49}$ Por. tamże 19, ed. Masullo, s. 76. 
Asklepios Leontuchos ${ }^{50}$, Tyandrites ${ }^{51}$, Asklepios z Epidauros ${ }^{52}$, Asklepios z Adratta ${ }^{53}$, Dioskurowie ${ }^{54}$, Pan i Attys ${ }^{55}$.

Za najważniejsze formy czci bogów uważano wtedy ofiary, modlitwy i komponowanie hymnów prozą lub w metrum ${ }^{56}$. Ta ostatnia forma kultu cieszyła się wielką estymą w środowisku neoplatońskim ${ }^{57}$. Kult Asklepiosa, któremu hołdował filozof, był znany z zaleceń komponowania hymnów terapeutycznych, liturgicznych i wotywnych ${ }^{58}$. Wobec tego, oprócz całonocnych modlitw i głośnego śpiewania hymnów, Proklos zabrał się również za ich samodzielne komponowanie. Marinos wspomina, że poza hymnami do bogów greckich pisał hymny do całego panteonu, w tym do tak egzotycznych bóstw, jak Marnas z Gazy, Asklepios Leontuchos z Askalonu, Tyandrites z Ezra czy Izyda z Filai ${ }^{59}$ - wszystkie wymienione bóstwa zostały pozbawione swych świątyń za życia Proklosa bądź niedługo potem ${ }^{60}$. Był to przejaw jego pobożności, którego nie zaniechał nawet po 70 roku życia (480-485), gdy zapadł na ciężką neurologiczną chorobę, uniemożliwiającą prowadzenie Akademii ${ }^{61}$. Śpiewał hymny do bogów-uzdrowicieli, ilekroć zachorował któryś z jego przyjaciół lub sam był chory ${ }^{62}$, znał na pamięć hymny orfickie i chętnie je recytował ${ }^{63}$.

Przekazane przez Marinosa informacje pozwalają wnioskować, że hymny Proklosa miały przeznaczenie kultowe zbliżone do misteryjnych Hymnów orfickich i peanów z Epidauros, adresowanych do bogów-uzdrowicieli. Sam hymn, jak wówczas uważano, był nie tylko formą modlitwy, lecz także formą

${ }^{50}$ Por. tamże.

${ }^{51}$ Por. tamże.

${ }^{52}$ Por. tamże 29, ed. Masullo, s. 86.

${ }^{53}$ Por. tamże 32, ed. Masullo, s. 88.

${ }^{54}$ Por. tamże.

${ }^{55}$ Por. tamże 33, ed. Masullo, s. 89-90.

${ }^{56}$ Por. tamże 1, ed. Masullo, s. 57.

${ }^{57}$ Por. Van den Berg, Proclus' Hymns, s. 13-30; zob. Damascius, Vita Isidori fr. 113, ed. Zintzen, s. 91 - Izydor (500-515), następca Marinosa i poprzednik Damascjusza w Akademii, kompo-

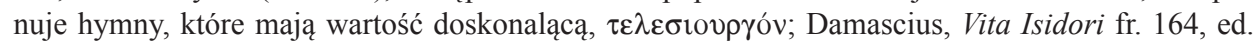
Zintzen, s. 137 - niejaki Asklepiades, specjalista od egipskiej teologii, komponuje hymny na cześć egipskich bogów.

${ }^{58}$ Por. m.in. Aelius Aristides, Hieroi logoi IV 39, ed. Keil, s. 435: „Asklepios polecił mi we śnie, bym komponował hymny nie tylko na jego cześć, ale wskazał mi jeszcze innych bogów, jak Pana, Hekate, Acheloosa i kogoś tam jeszcze. Atena sprawiła, że przyśnił mi się hymn na jej cześć zaczynający się od słów: Przyjdźcie, młodzieńcy, do Pergamonu...".

${ }^{59}$ Por. Marinus Neapolitanus, Vita Procli 19, ed. Masullo, s. 76.

${ }^{60}$ Por. P. Athanassiadi, Persecution and Response in Late Paganism: The Evidence of Damascius, JHS 113 (1993) 7.

${ }^{61}$ Por. Marinus Neapolitanus, Vita Procli 26, ed. Masullo, s. 82-83.

${ }^{62}$ Por. tamże 17, 20 i 29, ed. Masullo, s. 73, 77 i 86.

${ }^{63}$ Por. tamże 20, ed. Masullo, s. 77: „Gdy intonowaliśmy początek hymnu, on recytował środek i koniec. Były to zazwyczaj poezje orfickie; bo ilekroć byliśmy blisko niego, lubiliśmy recytować niektóre z nich". 
ofiary, a nawet jej ekwiwalentem ${ }^{64}$. Hymny Proklosa mogły być taką właśnie ofiarą zanoszoną do bogów-zbawicieli i patronów misteriów, podobnie jak peany z Epidauros i Hymny orfickie. Nic nie wskazuje na to, by którykolwiek z hymnów Proklosa, może z wyjątkiem Нутпи 6, miał charakter teurgiczny, to jest przyzywający Święty Ogień, pomocny w trzech rzeczach: odprawianiu czarów, duchowej koncentracji i wstępowaniu do $\mathrm{Ojca}^{65}$.

3. Bogowie Hymnów. Kolejną tezą Robberta M. Van den Berga, z którą trudno mi się zgodzić bez zastrzeżeń, jest twierdzenie, że wszyscy bogowie będący adresatami Hymnów należą do tzw. archontów ${ }^{66}$. Nie da się pokrótce wytłumaczyć, jakie miejsce w boskiej hierarchii Proklosa zajmują archonci, dlatego przedstawiam to na poniższym schemacie; archonci znajdują się w tabeli 1 po numerem V. Skomplikowana i niezwykle rozbudowana ontologia Proklosa dzieliła się na siedem światów, z których cztery pierwsze były niewidzialne, piąty i szósty - pośrednie, a ostatni siódmy - widzialny. Archonci, których nazwę Proklos zaczerpnął z Platońskiego Fajdrosa ${ }^{67}$, plasują się w piątym świecie i w czwartym porządku, tworząc wraz z dwunastoma bogami olimpijskimi tzw. Berło Fanesa. Proklos wymienia dwunastu archontów pogrupowanych w cztery triady: 1. Zeus, Pluton, Posejdon, 2. Hekate, Kora, Atena, 3. Apollon-Helios i 4. Trzej Korybanci.

Argumentuję niżej, że spośród archontów jedynie Apollon-Helios pasuje do Hyтnи 1, natomiast pozostali, których imiona pokrywają się z hymnicznymi (Hekate, Zeus, Atena) nie mogą być brani pod uwagę jako adresaci Hymnów 6 i 7. Bóstwa z Hymnów 1-7 są rozsiane na trzech poziomach boskości od IV do VI (w tabeli 1 zaznaczam je białymi literami na czarnym tle). Proklos skonstruował tę niezwykle skomplikowaną hierarchię bytów boskich $\mathrm{w}$ taki sposób, że uzgodnił rozbudowaną przez siebie neoplatońską ontologię z bóstwami występującymi w dialogach Platona, z Wyroczniami Chaldejskimi oraz z panteonem Rapsodii orfickich, do których miłością zaraził go Syrianos, diadoch Akademii w latach 433-43768. Księga Suda podaje, że Proklos napisał dziesięć ksiąg pt. Paralele między Orfeuszem, Pitagorasem $i$ Platonem $w$ kwestii Wyroczni chaldejskich ${ }^{69}$. Ten niezachowany traktat powstał w tym czasie, gdy Proklos współpracował z Syrianosem ${ }^{70}$.

${ }^{64}$ Por. Proclus, Hymnus 1, w. 44; Hymnus 5, w. 13 (zob. przekład niżej); Synesius Cyrensis, Hymnus 1(3), 8-11, éd. Lacombrade, s. 7: „Królowi bogów wieniec splatamy, ofiarę bez krwi, libację z poezji”; Porphyrius, De abstinentia II 34, 4, ed. J. Bouffartigue - S. Patillon: Porphyre: De l'abstinence, II, Paris 1979, Les Belles Lettres, 101: „Bogom noetycznym należy ofiarować hymn śpiewany na głos. Jest to pierwocina dla każdego z nich”.

${ }^{65}$ Por. A. Sheppard, Proclus' Attitude to Theurgy, CQ N.S. 32 (1982) nr 1, 212-224.

${ }^{66}$ Por. Van den Berg, Proclus' Hymns, s. 35-65.

${ }^{67}$ Por. Plato, Phaedrus 247a 2-3.

${ }^{68}$ Por. Marinus Neapolitanus, Vita Procli 26-27, ed. Masullo, s. 81-85.

${ }^{69}$ Por. Suda, Lexicon Pi 2473, ed. Adler, s.v. Proclus.

${ }^{70}$ Por. tamże Sigma 1662, ed. Adler, s.v. Syrianus (= tamże Pi 2473, ed. Adler, s.v. Proclus). 
Tabela 1. Boska hierarchia Proklosa

\begin{tabular}{|c|c|c|c|}
\hline \multicolumn{2}{|c|}{ Terminy neoplatońskie } & Rapsodie orfickie & Wyrocznie chaldejskie \\
\hline \multicolumn{4}{|c|}{ NIEWIDZIALNY OJCIEC } \\
\hline \multicolumn{2}{|l|}{ I. Jedno (๕̌v) } & Chronos & Niewyrażalne Jedno \\
\hline \multirow[t]{2}{*}{ Henady } & Dobroć & Wola & Opatrzność \\
\hline & $\begin{array}{l}\text { Pierwsza triada noetyczna: } \\
\text { 1-3. Kres, Bezkres, } \\
\text { Mieszanka }\end{array}$ & $\begin{array}{l}\text { Tajemny Bóg: } \\
\text { Eter, Chaos, Jajo }\end{array}$ & $\begin{array}{l}\text { Ojcowska Głębia: } \\
\text { Ojciec }\end{array}$ \\
\hline \multirow[t]{2}{*}{$\begin{array}{l}\text { II. Enneada } \\
\text { noetyczna }\end{array}$} & $\begin{array}{l}\text { Druga triada noetyczna: } \\
\text { 4-6. Kres, Bezkres, } \\
\text { Mieszanka }\end{array}$ & $\begin{array}{l}\text { Jajo kosmiczne: } \\
\text { Tunika, Chmura, } \\
\text { Embrion }\end{array}$ & Światło (Eon) \\
\hline & $\begin{array}{l}\text { Trzecia triada noetyczna: } \\
\text { 7-9. Kres, Bezkres, } \\
\text { Mieszanka }\end{array}$ & $\begin{array}{l}\text { Demiurg: Fanes, } \\
\text { Erikepajos, Metis }\end{array}$ & Kwiat Umysłu \\
\hline \multicolumn{4}{|c|}{ NIEWIDZIALNE NOCE $=$ IYNGES } \\
\hline $\begin{array}{l}\text { III. Enneada } \\
\text { noetyczno- } \\
\text { noeryczna }\end{array}$ & $\begin{array}{l}\text { Pierwsza triada noetyczno- } \\
\text { noeryczna } \\
\text { 1-3. Kres, Bezkres, } \\
\text { Mieszanka }\end{array}$ & Trzy Noce & $\begin{array}{l}\text { Trzy krążki magiczne } \\
\text { (iynges) }\end{array}$ \\
\hline \multirow[t]{4}{*}{$\pi \rho o ́ o \delta$ os } & $\begin{array}{l}\text { Druga triada noetyczno- } \\
\text { noeryczna }\end{array}$ & Uranos, Urania: & Wiążący (synocheis) \\
\hline & $\begin{array}{l}\text { 4-6. Kres, Bezkres, } \\
\text { Mieszanka }\end{array}$ & Trzej Cyklopi & \multirow[b]{2}{*}{$\begin{array}{l}\text { Rządcy }(\text { teletarchai })= \\
\text { Wiara, Nadzieja, } \\
\text { Miłość }\end{array}$} \\
\hline & $\begin{array}{l}\text { Trzecia triada noetyczno- } \\
\text { noeryczna } \\
\text { 7-9. Kres, Bezkres, } \\
\text { Mieszanka }\end{array}$ & Trzej Sturęcy & \\
\hline & NIEWIDZIALNE ŹRÓDŁC & $=$ WIELCY DEMIURC & OWIE \\
\hline \multirow{7}{*}{$\begin{array}{l}\text { IV. Hebdomada } \\
\text { noeryczna }\end{array}$} & Pierwsza triada noeryczna: & & Ojcowie Źródła: \\
\hline & 1. Pierwszy Umysł & Kronos H 6 & Pierwszy Ojciec \\
\hline & 2. Bogini Karmicielka & $\begin{array}{l}\text { Matka Bogów Rea } \\
\text { H } 6\end{array}$ & Hekate H 6 \\
\hline & 3. Umysł Demiurga & Zeus H 6 & \multirow{3}{*}{$\begin{array}{l}\text { Drugi Ojciec } \\
\text { Nieprzebłagani } \\
\text { (ameiliktoi) }\end{array}$} \\
\hline & 4-6. Druga triada & Pallas Atena H 7 & \\
\hline & $\begin{array}{l}\text { noeryczna: } \\
\text { Nieskalani }\end{array}$ & $\begin{array}{l}\text { Kora } \\
\text { Kureci }\end{array}$ & \\
\hline & 7. Monada podziału & $\begin{array}{l}\text { Kastracja Uranosa } \rightarrow \\
\text { Afrodyta Urania H } 2\end{array}$ & $\begin{array}{l}\text { Membrana } \\
\rightarrow \text { Kwiat Ognia }\end{array}$ \\
\hline
\end{tabular}




\section{Neoplatonizm}

Rapsodie orfickie, Wyrocznie chaldejskie, Platon

BERŁO FANESA = NIŻSI DEMIURGOWIE

V. Dodekada hiperkosmiczna

Dwunastu archontów:
triada stwórcza:
1. Zeus
2. Pluton
3. Posejdon
triada ożywicieli:
4. Artemida
5. Persefona
6. Atena

triada doskonaląca:

7-9. Apollon-Helios H 1

triada oczyszcza-

10-12. Korybanci

jąca:

VI. Dodekada hiper- Dwunastu bogów olimpijskich:

enkosmiczna
triada stwórcza:
1. Zeus
2. Posejdon
triada strażników:
4. Hestia
5. Atena
triada ożywicieli:
7. Demeter
8. Hera

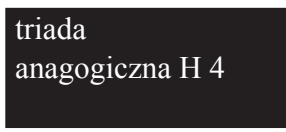
10. Hermes

\section{ŚWIAT WIDZIALNY = NATURA}
1. Bogowie nad Księżycem:
a. Kosmiczny Serce Dionizosa Umysł
b. Dusza Świata Ciało Dionizosa, Hipta
c. Cztery żywioły ogień, powietrze, woda, ziemia

3. Hefajstos

6. Ares

9. Artemida

$\begin{array}{cc}\text { 11. Afrodyta } & \text { 12. Apollon } \\ \text { Dionaia H } 5 & \begin{array}{c}\rightarrow \text { Muzy } \\ \text { H } 3\end{array}\end{array}$

VII. Tłum enkosmiczny

2. Sfery kosmiczne:
a. Gwiazdy stałe
b. Siedem planet: Saturn
Jupiter
Mars
Słońce
Wenus
Merkury
Księżyc

$\begin{array}{clll}\text { 3. Bogowie } & \text { Uranos } & \text { Gaia } & \text { Okeanos } \\ \text { pod Księżycem: } & \text { Tethys } & \text { Kronos } & \text { Rea } \\ & \text { Forkys } & \text { Zeus } & \text { Hera }\end{array}$

4. Bogowie ziemscy i podziemni

5. Półbogowie (dajmones)
a. Aniołowie
b. Złe demony = bestie Hekate
c. Herosi

6. Dusze cząstkowe: ludzie 
Obaj zaczęli pracę nad konstrukcją gigantycznego systemu teo-ontologicznego, w którym miały się znaleźć panteony wszystkich religii. Pseudo-Dionizy Areopagita, uczeń Proklosa pomiędzy 450 a 470 rokiem, podaje, że mistrz

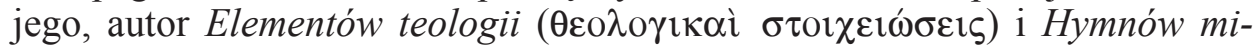

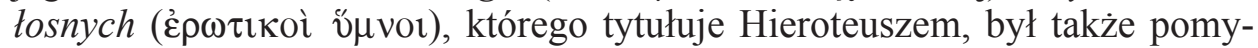
słodawcą wtłoczenia aniołów ze Starego Testamentu w enneadę ${ }^{71}$ Być może Serafiny, Cherubiny, Trony itd. miały zostać wcielone do największego politeistycznego systemu, jaki kiedykolwiek powstał dla zilustrowania zgodności wszystkich religii świata ${ }^{72}$.

Czy wobec tego uda się wyłowić z tego morza politeizmu bogów, którzy są adresatami Hymnów? Jak znaleźć tych właściwych, czyli jak zawęzić obszar poszukiwań? Na szczęście „teotaksonomia” Proklosa, tak jak każdy inny skomplikowany system, bazuje na znacznie prostszym schemacie. Tym kluczem do Proklosa jest Porfiriusz, który w swoim wykładzie o ofiarach naucza, że istnieją cztery rodzaje bytów boskich: (1) Bóg ponad bogami, któremu ofiarowuje się tylko czystą myśl i czyste milczenie, (2) bogowie noetyczni, którym śpiewa się hymny, (3) bogowie widzialni, dla których pali się ofiary z kadzidła, i (4) demony, którym składa się w ofierze krew ${ }^{73}$. Biorąc poprawkę na to, że „noetyczny” u Porfiriusza ma inne znaczenie niż u Proklosa, otrzymujemy schemat zasadniczo zgodny z Proklosem, za to zdecydowanie prostszy:

1 Niewidzialny Ojciec i Niewidzialne Noce (I-III w tabeli 1) to rozszerzona wersja Boga ponad bogami Porfiriusza. Nie dotyczą ich żadne formy ofiar, nie śpiewa się im hymnów na głos;

2 Niewidzialne Źródło (IV) i Berło Fanesa (V-VI) odpowiadają bogom noetycznym Porfiriusza, którym ofiarowuje się hymny - tu zatem należy szukać adresatów Hymnów Proklosa;

3 Bogowie kosmiczni (VII 1-4) to bogowie widzialni Porfiriusza, którzy wymagają ofiar bezkrwawych. Tego rodzaju bóstwa są adresatami Hymnów orfickich; utwory te precyzują, jakich ofiar (wonności, libacje, ziarno, pochodnia) wymaga dany bóg czy bogini;

4 Demony (VII 5b), żądne krwi, którym nie śpiewa się hymnów, za to składa ofiary ze zwierząt.

Wszyscy adresaci Hymnów Proklosa znajdują się w punkcie 2. Poza bogami z Hyтnu 6 należą oni do panteonu Rapsodii orfickich i dialogów Platona.

${ }^{71}$ Por. Pseudo-Dionysius, De divinis nominibus II 9-10; III 2; IV 15-16; De coelesti hierarchia VI 2 (cytuję według wydania: ed. B.R. Suchla - G. Heil - A.M. Ritter: Corpus Dionysiacum, I-II, Berlin 1990-1991, Gruyter; tłum. M. Dzielska: Pseudo-Dionizy Areopagita, Pisma teologiczne, wyd. 2 popr., Kraków 2005, Znak). Na temat związków między Pseudo-Dionizym a Proklosem zob. S. Klitenic Wear - J.M. Dillon, Dionysius the Areopagite and the Neoplatonist Tradition: Despoiling the Hellenes, Aldershot 2007, Ashgate.

${ }^{72}$ Przekonanie Proklosa o wewnętrznej zgodności wszystkich religii podzielali inni neoplatonicy, por. Damascius, Vita Isidori fr. 164, ed. Zintzen, s. 139. Dalsze szczegóły nt. politeistycznego i filozoficznego systemu Proklosa zob. R. Chlup, Proclus: An Introduction, Cambridge 2012, Cambridge UP.

${ }^{73}$ Por. Porphyrius, De abstinentia II 34-36, ed. Bouffartigue - Patillon, II, s. 100-103 = OF 635. 
Zanim przystąpię do analizy, przedstawiam pierwszy polski przekład Hymnów Proklosa. Starałam się oddać rytm oryginalnej wersyfikacji za pomocą tzw. heksametru polskiego. Zrezygnowałam z rymów, ponieważ poezja grecka nie jest rymowana.

\section{PRZEKŁAD*}

\section{Hymn 1 (Do Heliosa) ${ }^{74}$}

Usłysz, królu noerycznego ognia, złotolejcowy,

Usłysz, Tytanie, dawco światła, władco! Ty sam przecież

Klucz do źródła życia dzierżysz, ty w materii światy

Wlewasz z wysoka niewyczerpany strumień harmonii.

Słuchaj!

Ty mieszkasz zaiste w samym środku eteru,

Ty kontrolujesz olśniewający dysk - serce świata,

Ty przenikasz wszechrzeczy promieniem swej opatrzności.

Ty swych pochodni żarem nieustannie rozpalasz planety:

Wiecznie płoną, wiecznie tańczą i nigdy nie przestaną

Zsyłać ożywczych kropli na wszystkich mieszkańców ziemi.

Twój rydwan krąży po niebie, pory roku wyznacza.

W rytm twych okrążeń cykl narodzin wciąż się powtarza.

Gdy tylko wyłoniłeś się z ojca głębi tajemnej,

Ucichł natychmiast huk zderzających się żywiołów.

Chór Mojr niewzruszonych, nawet one ci ustępują:

Jeśli zechcesz, zaczną pruć swą przędzę - nić przeznaczenia.

Ty wszystkim władasz, o panie, nad wszystkim panujesz.

Febus, król pieśni, z twego wyskoczył łańcucha,

Słowa natchnione śpiewa $z$ akompaniamentem kitary,

Uspokaja wzburzone, ryczące fale narodzin.

Do Twego zbawczego kręgu należy także Pean,

Co słodkie dary, co słodkie zdrowie ludziom przynosi,

Co zbawienną harmonią świat szeroki napełnia.

Hymny sławią cię jako rodziciela Dionizosa,

Attysa Ewiosa, co krzyczy w głębinach materii,

Lub Adonisa pięknego, opiewanego w poezji.

Bicz twój szybki zdoła odpędzić, przerazić, powstrzymać

Dzikie serca i klęskę dla śmiertelników - demony,

Co wiecznie zgubę gotują naszym nieszczęsnym duszom,

Co pragną jednego: aby dusze zawsze cierpiały

* Przekładu z j. greckiego dokonano na podstawie: Procli hymni accedunt hymnorum fragmenta, epigrammata, scholia, fontium et locorum similium apparatus, indices, ed. E. Vogt, Wiesbaden 1957, Harrassowitz, 27-33. Zmiany w tekście greckim, przekład angielski i komentarz: R.M. Van den Berg, Proclus' Hymns: Essays, Translations, Commentary, Leiden 2001, Brill.

${ }^{74} \mathrm{~W}$ nawias ujęto tytuły hymnów dodane przez Gemistosa Plethona (1355-1454). 
W jarzmie ciała, w toni głośno huczącego żywota,

Ojca dworu wysokiego, jasnego niepomne.

O ty, z bogów najlepszy, promienny, szczęsny Dajmonie,

Obrazie Boga wszechstwórcy, przewodniku dusz naszych!

Racz mnie wysłuchać, racz z grzechów oczyścić na zawsze!

Prośbę mą łzawą przyjmij, zbaw od zmazy nieszczęsnej!

Strzeż mnie, proszę, przed Pojnai, zabierz je precz ode mnie!

Dike - wszystkowidzące oko niech wejrzy łaskawiej!

Broń mnie zawsze przed złem, zechciej wsparcia udzielać!

Daj mej duszy światło błogosławione i święte,

Mgły rozprosz opary, co zatruwa i zgubę przynosi!

Oby dane mi było szlachetnym zdrowiem się cieszyć!

Pozwól mi dobrej sławy dostąpić, a będę Cię wielbił

W przodków obrzędach i darach Muz o pięknych warkoczach.

Daj, Panie, jeśli łaska, wieczną szczęśliwość w nagrodę

Za mą pobożność. Wszakże ty możesz udoskonalać,

Cokolwiek zechcesz, bowiem moc twa nieograniczona.

Gdyby jakąś przeszkodę na naszej postawiły drodze

Nici gwiezdne, przędzione przez przeznaczenia wrzeciono,

Daj mi znać, proszę, swym ostrzegawczym migotaniem!

Hymn 2 (Do Afrodyty)

Afrogenei łańcuch opiewamy wieloimienny,

Źródło wielkie, królewskie, skąd wylatują

Wszystkie nieśmiertelne, skrzydlate Erosy.

Jedne z nich noerycznymi strzałami strzelają

Do dusz naszych, by je do wstępowania pobudzić,

Aż zatęsknią za matki swej dworem ognistym.

Inne Erosy z woli ojca, z woli opatrzności

Koło narodzin trzymają, kręcą nim nieustannie,

W duszach tęsknotę za ziemskim żywotem wzniecając.

Są też takie Erosy, co nucą pieśni weselne,

Co wtajemniczają w przeróżne małżeńskie misteria,

By ze śmiertelnych nieśmiertelną wyhodować rasę.

Matka Erosów, Cypryda, zatrudnia wszystkie swe dzieci.

Ty wszak, bogini, wszystko słyszysz i wszędzie masz uszy,

Bo, jak mówią, niebo ogromne otaczasz dokoła,

Jesteś tam ponoć wiekuistą, boską Duszą Świata,

A może w eterze mieszkasz, za siódmą orbitą.

Ty sama, o bogini, spajasz wasz łańcuch stalowy.

Słuchaj, Pani! Wyprostuj kręte ścieżki mego żywota,

Tak ciężko brnąć przez nie. Wystrzel sprawiedliwości strzały,

Kres połóż, proszę, na zawsze żądzom mym lodowatym! 


\section{Hymn 3 (Do Muz)}

Światło opiewamy, światło, które w górę wznosi,

Dziewięć córek wielkiego Zeusa o głosach donośnych.

One ratują dusze w życia odmętach błądzące

Od tego świata tutaj, od cierpień jego nieznośnych,

Przez ksiąg nieskalane misteria, co otwierają oczy.

Uczą, jak szybko ślad odnaleźć ponad Lete nurtami,

Jak czystość odzyskać, jak wrócić do gwiazdy pokrewnej,

Skąd spadliśmy, gdy wody narodzin nas wyrzuciły

$\mathrm{Na}$ życia brzegi, oszołomionych, w materii dziale.

Kres połóżcie, proszę, mej żądzy cielesnej, boginie,

Szał bachiczny we mnie rozbudźcie mądrymi mitami!

Ród mężów bezbożnych niech mnie zwieść nie zdoła

Z drogi świetlistej, świętej, pięknych owoców pełnej!

Z szumu narodzin błędnego, z wiru tego wyrwijcie

Duszę mą zagubioną ku światłu świętemu prowadźcie!

Obym mógł zawsze spijać miód z waszych uli, Muzy,

A mej elokwencji czar niech po wsze czasy trwa!

\section{Hymn 4 (Hymn wspólny do bogów)}

O bogowie, co świętej mądrości dzierżycie stery,

Raczcie wysłuchać i wzniosły ogień rozpalić w duszach,

By zabrać je do nieśmiertelnych, gdy już opuszczą

Tę mroczną jamę, gdy oczyszczą się w misteriach hymnów.

Wielcy zbawiciele, słuchajcie! Z waszych ksiąg natchnionych

Światło święte mi dajcie i mgłę wokół mnie rozproszcie,

Bym zdołał rozpoznać nieśmiertelnego boga i człowieka!

Niech demon, dusz gnębiciel, nie trzyma mnie długo

$\mathrm{Z}$ dala od bogów szczęśliwych, w niepamięci odmętach!

Oby moja dusza, wpadłszy w zimne wody narodzin,

Nie musiała błąkać się tutaj bez końca wbrew sobie,

W życia kajdany zakuta przez lodowatą Pojne.

O bogowie, o przewodnicy jaśniejącej mądrości!

Raczcie mnie teraz wysłuchać! Na górną wkraczam drogę.

Święte symbole misteriów, święte słowa objawcie!

\section{Hymn 5 (Do Afrodyty Licyjskiej)}

Hymn śpiewam na cześć Kurafrodyty, królowej Licji.

Dawno temu natchnieni przywódcy naszego narodu,

Wdzięczni bogini za pomoc, przed nieszczęściem obronę,

W naszym mieście ojczystym święty wizerunek wznieśli.

Posąg ten trzyma w ręku symbol mistycznych zaślubin 
Związku Afrodyty Urania z Hefajstosem ognistym.

Zwą tę boginię również przydomkiem Olimpijskiej,

Bo zbawia ludzi od śmierci - trucizny zabójczej.

Ma wzrok utkwiony w Cnotę. Cóż za pokolenie,

Cóż za ludzie niezłomni z tego łoża wyrośli!

Życie wiedli spokojne jak morze w słoneczny dzień.

Racz teraz, pani, przyjąć łaskawie naszą ofiarę,

Ze słów pięknych ofiarę. Licyjska krew we mnie płynie.

Przywróć pierwotne piękno mej oszpeconej duszy,

By uciekła przed żganiem ziemskiej żądzy ościenia.

Hymn 6 (Hymn wspólny do [Matki Bogów] ${ }^{75}$, Hekate i Janusa)

Witaj, Matko Bogów, szlachetna, wieloimienna!

Witaj i ty, wszechmocna pani, Hekate z Przedsionka!

Witaj, Janusie praojcze, witaj najwyższy Zeusie!

Raczcie jasno oświecić drogę mojego żywota,

Dobrem wszelakim napełnić! Zgubne choroby oddalcie

Od członków ciała! Duszę na ziemi tej oszalałą

Raczcie stąd zabrać, w inicjacjach oczyścić, obudzić!

Tak, błagam, rękę podajcie, wskażcie drogę do Boga!

Tego gorąco pragnę: światło lube oglądać,

Wyrwać się już, uciec przed losem niebieskich narodzin.

Tak, błagam, rękę podajcie, tak bardzo jestem zmęczony.

Niech wiatry skierują mój okręt do pobożności portu!

Witaj, Matko Bogów, szlachetna, wieloimienna!

Witaj i ty, wszechmocna pani, Hekate z Przedsionka!

Witaj, Janusie praojcze, witaj najwyższy Zeusie!

\section{Hymn 7 (Hymn do przemyślnej Ateny)}

Słuchaj mnie, córko Zeusa z Egidą, co z ojcowskiego

Źródła wytrysłaś, z najwyższego łańcucha! Wysłuchaj!

Ojca silnego tyś córa, męska duchem, Pallada

Tritogeneia w pozłocistym hełmie, z tarczą i włócznią!

Słuchaj, pani, i przyjmij ten hymn mój z sercem życzliwym!

Niech me słowa nie będą na wiatr rzucane daremnie!

Tyś to boskiej mądrości wrota szeroko rozwarła,

Tak poskromiłaś ród Gigantów, ziemskich wrogów Boga.

Nie uległaś zalotom zakochanego Hefajstosa

I zachowałaś nietknięty pas dziewiczy ze stali.

Tyś to uratowała bijące serce Bachusa

Pana, w głębi eteru pokrajanego na części

${ }^{75}$ Uzupełnienie dokonane przez Van den Berg, Proclus' Hymns, s. 252. 
Rękami Tytanów, a potem oddałaś je ojcu,

By zgodnie z ojca nieprzeniknionym planem Nowy

Dionizos przyszedł na świat, spłodzony przezeń z Semele.

Tyś to toporem swoim wykarczowała bydlęce łby

Żądz wszystkowidzącej Hekate, uśpiłaś narodziny.

Tyś ukochała cnót siłę, co budzi śmiertelnych,

Tyś upiększyła nasze życie swoimi sztukami,

Tyś w duszach zasiała ferment noerycznej sztuki!

Tyś to otrzymała Akropol, niedostępny wzgórek,

Symbol, o pani, twojego najwyższego łańcucha.

Tyś umiłowała ową ziemię żyzną, ksiąg matkę,

Wbrew świętemu pragnieniu twego stryja - brata ojca,

Dałaś miastu swe imię, dałaś i serce szlachetne!

Tam to, nieopodal szczytu, zaszczepiłaś oliwkę

Dla przyszłych pokoleń na pamiątkę owej bitwy,

Co rozegrała się, gdy Posejdon na Kekropidów

Wał zwalił ogłuszająco szumiącej wody. Potok

Lunął potężny i wszystko na swej drodze zatapiał.

Słuchaj mnie, pani, twe oblicze blask święty roztacza!

Daj mi przystań szczęśliwą, gdy tak się tułam po ziemi!

O, daj mojej duszy święte światło z twoich boskich mitów!

Daj mądrość, daj miłość, a w miłość tchnij siłę tak wielką

Iż nawet z objęć ziemi dusza się wyrwie i wzleci

$\mathrm{Z}$ tego padołu prosto na Olimp, ku ojca siedzibie.

Będę błądzić, jak to w życiu, będę grzeszyć zapewne -

Wiem o tym, miotam się raz w jedną, raz w drugą stronę,

W głupocie swojej ciągle czyny niegodne popełniam -

Zmiłuj się, łaskawa, nade mną, nie pozwól, zbawczyni,

Bym stał się pastwą straszliwych Pojnai, w prochu pełzając.

Ja przecież błagam o jedno - bym, o bogini, był twoim!

Daj zdrowie członkom osłabłym, by silne były i mocne,

Precz przegnaj ode mnie chorób chmary, co ciało zżerają!

Tak, błagam, królowo, swym ambrozyjskim ramieniem

Zło całe powstrzymaj czarnych męczarni i bólów!

Ześlij pomyślne wiatry w żegludze przez morze życia,

Daj małżeństwo, potomstwo, sławę, szczęście i radość!

Siłę perswazji, przyjaciół, umysł lotny jak Kronos,

Siłę do walki z wrogami, poczesne miejsce u ludów.

Słuchaj, ach słuchaj, królowo, mych modłów błagalnych,

Gdy mię konieczność przyciśnie, ucha nadstaw życzliwie! 


\section{KOMENTARZ}

\section{Hymn 1}

Hymn do Heliosa, który otwiera zbiór, poświęcony jest bogu szczególnie czczonemu przez Proklosa ${ }^{76}$. Starożytni chętnie pisali hymny na cześć tego bóstwa, stąd mamy pełny ich wybór: hymn homerycki ${ }^{77}$, hymn orficki ${ }^{78}$, piękne pieśni Mezomedesa ${ }^{79}$, hymny magiczne ${ }^{80}$, nonniański hymn do Heraklesa Astrochitona $^{81}$, prozaiczny hymn Juliana Apostaty Na cześć króla Heliosa do Salustiusza $^{82}$, orficki Hymn do Heliosa ${ }^{83}$, rekonstruowany na podstawie Makrobiusza $^{84}$, który skorzystał z jakiegoś wcześniejszego neoplatońskiego komentarza do tego utworu, i jeszcze jeden hymn orficki do Apollona-Heliosa ${ }^{85}$, rozpoczynający tasiemcowe Rapsodie orfickie w 24 księgach $^{86}$. Większość $\mathrm{z}$ nich żywo przypomina Hymn 1 tak w treści, jak w formie. Mimo to Van den Berg wytrwale poszukuje chaldejskiego wzorca ${ }^{87}$. Spośród wyżej wymienionych bierze pod uwage jedynie wpływ Juliana, bo cesarz, jak argumentuje, wzorował swą mowę na Jamblichu z Chalkis ${ }^{88}$, a ponieważ Jamblich to chodząca teurgia, zatem i hymn Juliana musi być teurgiczny. Nie jest uzasadnione, jak wykażę niżej, rozpatrywanie Hymnu 1 wyłącznie w kontekście Wyroczni chaldejskich przy jednoczesnym ignorowaniu lub zaprzeczaniu oczywistym wpływom innych utworów.

Lokalizacja Heliosa w wielkim łańcuchu bytów nie nastręcza trudności. Bóstwo opiewane jako noeryczne (w. 1) i doskonalące (w. 46) musi być Heliosem-Apollonem, przywódcą trzeciej triady archontów, doskonalącej, uplasowanym w boskiej hierarchii na poziomie V 7-9 (tabela 1), którego widzialnym (ale bynajmniej nie materialnym ${ }^{89}$ ) przejawem jest słońce z pozycji VII $2 b$. Ojcem Heliosa (w. 13) jest Zeus - Umysł Demiurga z pozycji IV 3, opiewany

\footnotetext{
${ }^{76}$ Por. Marinus Neapolitanus, Vita Procli 22, ed. Masullo, s. 78.

${ }^{77}$ Por. Hymni Homerici 31, ed. Evelyn-White, s. 458-459.

${ }^{78}$ Por. OH 8, ed. Ricciardelli, s. 26-29.

${ }^{79}$ Por. Mesomedes, Fragmenta, DAGM 26-27 i 30.

${ }^{80}$ Por. PGM II 88-103 i IV 591-603, 1596-1715.

${ }^{81}$ Por. Nonnus Panopolitanus, Dionysiaca 40, 366-411, ed. Rouse, III, s. 180-183.

${ }^{82}$ Por. Julianus, Oratio IV (XI), ed. Wright, I, s. 353-442.

${ }^{83}$ Por. OF 538-545.

${ }^{84}$ Por. Macrobius, Saturnalia I 17-23, ed. R.A. Kaster, I, Cambridge MA 2011, Loeb, 206-307.

${ }^{85}$ Por. OF 102.

${ }^{86}$ Omówienie większości z wymienionych utworów dają W. Fauth, Helios Megistos: Zur synkretistischen Theologie der Spätantike, Leiden 1995, Brill; H.D. Saffrey, La dévotion de Proclus au Soleil, w: Philosophies non chrétiennes et christianisme, éd. J. Sojcher-G. Hottois, Bruxelles 1984, 73-86; E. Heitsch, Drei Helioshymnen, „Hermes” 88 (1960) 139-158.

${ }^{87}$ Por. Van den Berg, Proclus' Hymns, s. 145-189.

${ }^{88}$ Faktycznie, sam Julian przyznaje to w Oratio IV(XI) 26, 146b, ed. Wright, I, s. 398.

${ }^{89}$ Neoplatonicy uważali, że blask słońca jest boski i mistyczny, por. np. zachwyty Juliana Apostaty w Oratio IV(XI) 1, 130b-131a, ed. Wright, I, s. 351-354.
} 
w Hymnie 6. Proklos szeroko pisze o miejscu Heliosa w hierarchii i jego funkcji w świecie materialnym w swoich pismach filozoficznych ${ }^{90}$.

Inwokacja (w. 1-5) nawiązuje do klamrowej kompozycji orfickiego hymnu do Heliosa, który zaczyna się od i kończy na „usłysz” (Hymn 1, w. 1 i 5) ${ }^{91}$. Poszczególne wyrazy i epitety zostały zapożyczone z hymnów magicznych i or-

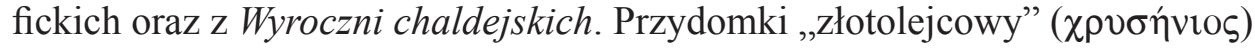

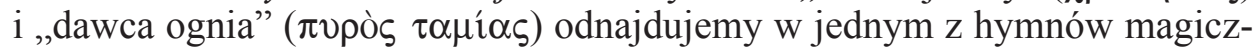
nych $^{92}$. Ten drugi występuje także w Wyroczniach chaldejskich ${ }^{93}, \mathrm{z}$ tym, że jest to oklepany epitet, a nie wyraz specyficznie chaldejski ${ }^{94}$. „Klucz” to najczęstszy atrybut bóstw późnoantycznych ${ }^{95}$, zaś kosmiczna harmonia wystąpiła już w orfickim hymnie do Heliosa ${ }^{96}$. „Noeryczny ogień” pojawia się dwukrotnie w Wyroczniach chaldejskich ${ }^{97}$, cytowanych przez Proklosa ${ }^{98}$.

Aretologia (w. 4-32) rozpada się na trzy części. Pierwsza sekcja (w. 5-17) sławi słońce - widzialny aspekt Heliosa, zrodzonego z „ojca” (w. 14), czyli Zeusa, Umysłu Demiurga. Neoplatonicy, podzielając opinię teurgów chaldejskich $^{99}$, uważali, że słońce zajmuje centralną pozycję pomiędzy trzema wyższymi planetami (Saturnem, Jupiterem, Marsem) a trzema niższymi (Wenus, Merkurym i Księżycem, por. VII $2 \mathrm{~b}$ w tabeli 1 ), stąd nadawali mu nazwę „,́rodka” i ,serca świata” (w. 5-6) ${ }^{100}$. Hymny orfickie ${ }^{101}$, Mezomedes - kompo-

${ }^{90}$ Por. Proclus, In Platonis Timaeum commentaria, ed. E. Diehl, I-III, Lipsiae 1903-1906, tutaj: III 80; Theologia Platonica VI 12, ed. Saffrey - Westerink VI 56, 1 - 65, 3.

${ }^{91}$ Por. OH 8, 1 i 20, ed. Ricciardelli, s. 26-28, thum. Żybert, s. 64.

${ }^{92}$ Por. PGM II 88-92: „Witaj, dawco ognia, daleko widzący władco świata, Heliosie na sławnych rumakach, oko Zeusa, które włada ziemią, wszystkowidzące, na podniebnym szlaku, z nieba schodzące i do nieba idące, błyszczące niedosiężne, świecące od zawsze, niewzruszone, w złotej koronie, z dyskiem w ręku, potęgo ognia, w lśniącym pancerzu, skrzydlaty, niezmordowany, złotolejcowy, złotym szlakiem bieżący. Biegnąc dookoła, wszystkich widzisz i słyszysz”, podkreślenie moje [E.O.].

${ }^{93}$ Por. OC 60, ed. Majercik, s. 72: „Słyszałem, że teologowie nazywają ogień strumieniem ognia, a słońce dawca ognia i tym podobnie".

${ }^{94}$ Por. Lewy, Chaldean Oracles and Theurgy, s. 154, nota 324.

${ }^{95}$ Por. m.in. PGM IV 341, VII 788; OC 197; OH 1, 7; 2, 5; 25, 1; 58, 4-5; Nonnus Panopolitanus, Dionysiaca VII 23 i IX 86.

${ }^{96}$ Por. OH 8, 10, ed. Ricciardelli, s. 26.

${ }^{97}$ Por. OC 37, 5 i 81, 1, ed. Majercik, s. 62 i 84.

${ }^{98}$ Por. Proclus, In Platonis Parmenidem III 800, 20, ed. C. Steel, I-III, Oxford 2007-2009, Clarendon, tutaj: I, s. 210; tamże IV 941, 21, ed. Steel, II, s. 131.

${ }^{99}$ Por. OC 58-59, ed. Majercik, s. 70-72.

${ }^{100}$ Por. tamże 58 = Proclus, In Platonis Rem publicam commentarii, II, ed. W. Kroll, Leipzig 1901, Teubner, 220, 11-18: „Słyszałem od chaldejskich teurgów, że Bóg umieścił Słońce pośrodku orbit siedmiu planet i uczynił pozostałe sześć zależnymi od niego, a od samych bogów słyszałem, że światło słoneczne znajduje się w tym miejscu co serce. Idę więc za głosem boskiego objawienia"; zob. także Julianus, Oratio IV (XI) 43, 156d, ed. Wright, I, s. 428: „Helios - środek środka”.

${ }^{101}$ Por. OH 8 Do Heliosa; OH 43 Do Hor; OH Prologus, 18 (Hory), ed. Ricciardelli, s. 26-28, 118, 8. 
zytor z czasów Hadriana ${ }^{102}$ i współczesny Proklosowi poeta Nonnos ${ }^{103}$ wierzą, że Helios objeżdża niebo na ognistym dysku (w. 6) w towarzystwie Likabantu, czyli roku, i jego córek Hor - bogiń jesieni, zimy, lata i wiosny (w. 12). Z tej racji, że centralnie umieszczone słońce decyduje o ruchu pozostałych sześciu planet, przypisywano mu również władzę nad Mojrami (w. 15-17) kontrolującymi planety za pomocą swych nici (w. 48-49). Hymny magiczne ${ }^{104} \mathrm{i}$ orfickie $^{105}$ wymieniają trzy Mojry podporządkowane Heliosowi: Kloto, Atropos i Lachesis. Proklos w innych swoich pismach ${ }^{106}$ wymienia te same imiona.

Druga sekcja (w. 18-26) przechodzi do wyższego Heliosa (por. V 7-9 w tabeli 1), który i sam jest demiurgiem, i zapoczątkowuje „łańcuch” niższych demiurgów: Febusa (w. 19-20), Peana (w. 22), Dionizosa (w. 24), Attysa (w. 25) i Adonisa (w. 26). Attys jest u Proklosa, podobnie jak u Juliana Apostaty ${ }^{107}$, potomkiem Heliosa i niższym demiurgiem, który schodzi aż do świata materii

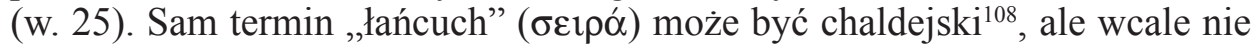
musi. Wyraz ten jest dobrze poświadczony w literaturze orfickiej ${ }^{109}$, cytowanej przez Proklosa ${ }^{110}$. Wiele przemawia za tym, że cała sekcja jest bardziej orficka niż chaldejska, ponieważ zachowany u Makrobiusza orficki hymn do Heliosa ${ }^{111}$ wyjaśnia fenomen tego boga na zasadzie ,jedności w wielości” (દ̌v $\tau$ ò $\pi \hat{\alpha} v)^{112}$, wymieniając wiele różnych bóstw, które konstytuują ciało solarne. Lista jest długa, znaleźli się na niej m.in.: Apollon, Faeton, Pean, Febus, Fanes, Likabant, Dionizos, Ares, Hermes, Herakles, Adonis, Attys, Ozyrys, Sarapis, Mitra, Eon, Nemezis, Pan i Adad - wszystkie, które podaje Proklos w Hymnie 1 i wiele ponadto. Alberto Bernabé ${ }^{113}$ rekonstruuje część hymnu do Heliosa w następujący sposób:

${ }^{102}$ Por. Mesomedes, Fragmenta, DAGM 27.

${ }^{103}$ Por. Nonnus Panopolitanus, Dionysiaca XII 1-28 (Hory); zob. także tamże XL 366-371 „Astrochitonie Heraklesie, panie ognia, świata władco, Heliosie, pasterzu życia! Ty cień rzucasz długi, całe niebo konno objeżdżasz na dysku ognistym. Ty Rok dwunastomiesięczny, syna Chronosa, wozisz ze sobą, ty krąg za kręgiem zataczasz, za waszym rydwanem wiek starości i młodości płynie!" (ed. Rouse, III, s. 180).

${ }^{104}$ Por. PGM II 200.

${ }^{105}$ Por. OH 59 Do Mojr, ed. Ricciardelli, s. 154-156.

${ }^{106}$ Por. Proclus, In Platonis Rem publicam commentarii, ed. Kroll, II 244; Theologia Platonica VI 23, ed. Saffrey - Westerink VI 99, 22 - 109, 17.

${ }^{107}$ Por. Julianus, Orationes V(VIII) 3, 161c-162a, ed. Wright, II, s. 450.

${ }^{108}$ Por. OC 203, ed. Majercik, s. 124; Synesius Cyrensis, Hymni 1(3), 230 i 2(4), 192, éd. Lacombrade, s. 50 i 65.

${ }^{109}$ Por. OF 98iv; OF 237.

${ }^{110}$ Proclus, In Platonis Cratylum commentaria 105, ed. G. Pasquali, Leipzig 1908, 54, 21; tenże, In Timaeum Platonis commentaria, ed. Diehl, II 24, 23-24.

${ }^{111}$ Por. OF 538-545; zob. też Macrobius, Saturnalia I 17-23, ed. Kaster, I, s. 206-307.

${ }^{112}$ Macrobius, Saturnalia, I 17, 4, ed. Kaster, I, s. 208.

113 Por. Orphicorum et Orphicis similium testimonia et fragmenta, ed. Bernabé, fasc. 2, s. 113-120. 
„Usłysz ty, co zawsze na podniebnej orbicie

Dysk promienny obracasz w ruchach wirowych,

Zeusie Dionizosie sławny, ojcze morza, ojcze ziemi,

Heliosie, ojcze świata, wszechpromienny, złoty! (OF 539)

Eter boski, niezmienny spuścił na ziemię,

Bogom objawił Erosa, cud dla oczu.

Teraz nazywają go Fanesem i Dionizosem,

I Eubuleusem władcą, i Antaugesem jasnym,

Każdy z ludów na ziemi innym go zowie imieniem.

$\mathrm{Na}$ światło pierwszy przyszedł, zwał się Dionizos,

Bo kręci się wkoło niebotycznego Olimpu.

Wciąż zmienia imiona, różne nazwy przybiera

W różnych czasach u różnych narodów (OF 540) ${ }^{114}$.

Helios, którego również nazywają Dionizosem. (OF 542)

Jeden Zeus, jeden Hades, jeden Helios, jeden Dionizos

Jeden bóg we wszystkich. Po co o każdym mówić z osobna? (OF 543)

Ma umysł swego ojca i jego przemyślność. (OF 544)

Twe łzy zamieniają się w rodzaj ludzki nieszczęsny,

Twój uśmiech stwarza ród bogów najświętszy.” (OF 545)

Interesujące paralele stanowią także synkretyczny hymn do Heraklesa Astrochitona, który wylicza wiele imion Heliosa ${ }^{115}$, oraz hymn z prologu Rapsodii, łączący Apollona z Heliosem ${ }^{116}$. Kaskadowej identyfikacji bóstw z Heliosem przyświeca mistyczna idea teokrazji ${ }^{117}$, która nie jest chaldejska, lecz orficka.

Trzecia sekcja (w. 21-32) skupia się na apotropaicznych właściwościach Heliosa. Bóstwo, jak wierzy autor, ma moc odpędzania złych demonów (por. VII $5 \mathrm{~b}$ w tabeli 1) swym biczem, normalnie używanym do popędzania solarnych rumaków ${ }^{118}$ (w. 27-28). W zakończeniu hymnu (w. 48-50) filozof prosi

${ }^{114}$ Por. J. Sfameni Gasparro, OF 540 = Macrobio, Sat. I 18, 12 e Inno orfico 52: Dioniso tra teogonia e attualità religiosa, w: Tracing Orpheus. Studies of Orphic fragments. In honour of Alberto Bernabé, ed. M. Herrero, Berlin 2011, Gruyter, 255-260. Pomijam z braku miejsca następny fragment OF 541, który dotyczy solarnego Dionizosa.

${ }^{115}$ Por. Nonnus Panopolitanus, Dionysiaca XL 392-411, ed. Rouse, III, s. 182: „Jesteś Belem nad Eufratem, Ammonem w Libii, Apisem nad Nilem, Kronosem w Arabii, Zeusem w Asyrii, ... Sarapisem - Zeusem bezchmurnego Egiptu. Wieloimienny jesteś, zwiesz się Kronosem, Faetonem i Mitrą, Heliosem Babilonu, delfickim Apollonem w Helladzie, Gamosem, nasieniem Erosa i Zeusa snów bezwstydnych, ... Peanem, co ból uśmierza, Eterem cętkowanym albo Astrochitonem, bo nocą ubierasz niebo w chiton upstrzony gwiazdami. Jakkolwiek cię zwą, wysłuchaj życzliwie mej prośby!”.

${ }^{116}$ Por. OF 102, ed. Bernabé, fasc. 1, s. 110-111: „Władco, synu Latony, dalekosiężny, Febusie potężny! Wszystkowidzący, królu śmiertelników i nieśmiertelnych, Heliosie, co fruwasz na złotych skrzydłach!”.

${ }^{117}$ Por. Damascius, Vita Isidori fr. 174, ed. Zintzen, s. 147, thum. pol. w nocie 219.

${ }^{118} \mathrm{Na}$ temat przedstawień Heliosa z biczem w dłoni zob. D. Levi, Aion, „Hesperia” 13 (1944) 303-304. 
boga o ochronę przed złym losem. Dysponujemy papirusem magicznym ${ }^{119}$, który opisuje rytuał poświęcenia amuletów ochronnych właśnie Heliosowi Agathodajmonowi Sarapisowi. Możliwe, że amulety ochronne ( $\varphi v \lambda \alpha \kappa \tau \eta \dot{\rho} \rho \iota)$, które produkował Proklos przeciw trzęsieniu ziemi ${ }^{120}$, były także poświęcone Heliosowi. „Dwór ojca” (w. 32) to termin teurgiczny, który autor szczegółowo wyjaśnia w swych komentarzach do chaldejskiej filozofii ${ }^{121}$.

Modlitwa (w. 33-50) zaczyna się od krótkiej inwokacji (w. 33-34), w której Helios jest wzywany imionami „Dajmon” i „obraz boga wszechstwórcy”. Dajmon był grecko-egipskim bogiem narodzin ${ }^{122}$, identyfikowanym ze słońcem; za pozostałe bóstwa narodzin uważani byli Tyche-Księżyc oraz Eros i Ananke, symbolizowani przez pocałunek i węzeł ${ }^{123}$. Drugie imię czy epitet,

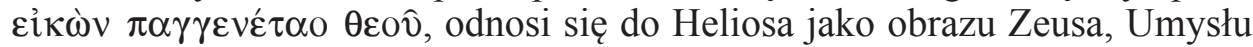
Demiurga. Hans Lewy ${ }^{124}$ i Robbert M. Van den Berg ${ }^{125}$ są przekonani, że chodzi tu o chaldejską koncepcję słońca jako obrazu Eona (zob. II 4-6 w tabeli 1), nota bene bóstwa niewymienianego z imienia w Wyroczniach chaldejskich. Dwa popularne hymny: jeden Mezomedesa, drugi magiczny z tzw. „Liturgii Mitry" faktycznie wspominają Eona w podobnym kontekście ${ }^{126}$.

${ }^{119}$ Por. PGM IV 1596-1715.

${ }^{120}$ Por. Marinus Neapolitanus, Vita Procli 28, ed. Masullo, s. 84.

${ }^{121}$ Por. Proclus, Eclogae de philosophia Chaldaica 1, ed. Iahnius, s. 1: „Dwory ( $\left.\alpha \hat{\lambda} \lambda \alpha i ́\right)$ i mieszkania bogów są to wieczne szeregi. Wszechobejmujący dwór Ojca jest to szereg ojcowski, który obejmuje i mieści w sobie wszystkie dusze, które wstąpiły do nieba. Jak to się dzieje, że hierarchia anielska unosi duszę? W taki mianowicie sposób, że ogrzewa ją ogniem, tj. oświeca i napełnia nieskalanym ogniem, stawia mocno w szeregu i daje siłę, aby nie spadła w chaos materii, ale dołączyła do boskiego światła. Życiodajna siła pozwala duszy utrzymać się na właściwym jej miejscu, nie mieszać z materią, być lekką i wznieść się wraz z gorącym Pneuma; bo właśnie gorące Pneuma jest tchnieniem życia, dzięki któremu dusza szybuje wysoko w górę, tak jak pod ciężarem spada ku materii. Celem wstępowania jest spożywanie boskich owoców i stopienie się z ogniem, który jest wizją Boga, naoczną wizją Ojca. Dusza jest jak śpiewak hymnów, który dopełnia boskich rytuałów; przynosi ona Ojcu, wedle wyroczni, niewyrażalne symbole Ojca, które on sam jej dał przy pierwszym wejściu w byt. Te noeryczne i niewidzialne hymny, które wznosi wstępująca dusza, budzą wspomnienia - o słowach pełnych harmonii, o niewyrażalnych obrazach, wreszcie o boskich mocach, które w niej tkwią". Por. także hymny Synezjusza z Cyreny (Synesius Cyrensis, Hymni 1[3] 37, 710 i 2[4], 292, éd. Lacombrade, s. 7, 60, 67), gdzie wyraz „dwór” należy do ulubionych.

${ }^{122}$ Por. OH 73 Do Dajmona, ed. Ricciardelli, s. 186.

${ }^{123}$ Por. Macrobius, Saturnalia I 19, 17, ed. Kaster, I, s. 266.

${ }^{124}$ Por. Lewy, Chaldean Oracles and Theurgy, s. 150-155.

${ }^{125}$ Por. Van den Berg, Proclus' Hymns, s. 154.

${ }^{126}$ Por. Mesomedes, Fragmenta, DAGM 30, 14-23: „Ty jasnymi promieniami całą ziemię opromieniasz, Aionie niegasnących płomieni, wejrzyj na mnie swoimi oczami, wlej czyste szczęście w swego szaleńca, Peanie! Do Ciebie, moje życie, dążę, choć w słabym ciele mieszkam. Zmiłuj się nade mną, Tytanie! Jestem w więzieniu i boję się”; PGM IV 591-603 („Liturgia Mitry”): „Płonący ogniu PENTITEROUNI, stwórco światła SEMESILAM, oddechu ognia PSYRINPHEU, duchu ognia IAO, duchu światła OAI, wielbicielu ognia ELOURE, piękne światło AZAI, Aionie AKBA, panie światła PEPPER PREPEMPIPI, ciele ognia PHNOUENIOCH, dawco światła, siewco ognia AREI EIKITA, morze ognia GALLABALBA, żywy ogniu IAIAIO, wirze ognia PYRICHI BO- 
Autor prosi o ochronę nie tylko przed złymi demonami, które wikłają duszę w kolejne wcielenia (w. 28-32), lecz także o wsparcie w konfrontacji z mściwymi boginiami, Pojnai i Dike (w. 37-38). Według Proklosa Dike, prawa ręka Zeusa Stwórcy (V 1 i VI 1 w tabeli 1), miała szerokie kompetencje: rządziła bogami kosmicznymi, kontrolowała dajmones i karała dusze ludz$\mathrm{kie}^{127}$. Jednym słowem była opatrznością całego świata widzialnego (VII w tabeli 1), stąd jej symbolem jest u Proklosa wszystkowidzące oko (w. 38) ${ }^{128}$. Tej wiecznie zajętej bogini przydawano liczne asystentki, m.in. wściekłe Erynie $^{129}$, Nemezis z kołem losu ${ }^{130}$ i surowe Pojnai, czyli Kary ${ }^{131}$. „We wszystkim go [tj. Zeusa] słuchała pomocniczka Dike, która ma wiele Pojnai”, mówią Rapsodie orfickie ${ }^{132}$. Spekulacje medioplatońskie uczyniły z Pojne personifikację kar naprawczych, ponoszonych w ciele i poprzez ciało ${ }^{133}$. Proklos rozumuje w podobnym sensie: Pojne to kara odbierana podczas wcielenia i przez sam fakt wcielenia (Hymn 4, w. 2) $)^{134}$.

Modlitwa o zesłanie światła i rozproszenie mgły (w. 40-41, por. Hymn 4, w. 6) zawiera podtekst. Julian Apostata w swoich mowach antiocheńskich z $362 \mathrm{r}$. twierdzi, że Helios, jego osobisty bóg opiekuńczy, powierzył mu misję zbawienia świata od „chmury ateizmu” 135 . Oczywiście tą czarną chmurą, która przesłoniła słońce imperium, było dla Juliana chrześcijaństwo. Proklos skarży się nieśmiało na nietolerancję chrześcijan w Hymnie 7, zaś tu (w. 43-45) przedstawia własną pobożność w terminach tradycyjnych wartości. „Tradycyjne” w jego ustach zawsze znaczy „pogańskie”. Zatem można przypuszczać, że przez „święte światło” rozumie pogaństwo, natomiast przez „toksyczną mgłę” - chrześcijaństwo.

\section{Hymn 2}

Jeden z dwu hymnów do Afrodyty natychmiast stawia przed Czytelnikiem pytanie, czy jego adresatką jest ta sama bogini, do której Proklos ułożył drugi hymn - Hymn 5. Robbert M. Van den Berg odpowiada twierdząco na to pyta-

OSEIA, światło w ruchu SANCHEROB, miotaczu piorunów IE OE IOEIO, sławne światło BEEGENETE, pomnożycielu światła SOUSINEPHI, który podtrzymujesz światłość...”, podkreślenie moje [E.O.]. WIELKIE LITERY oznaczają voces magicae.

${ }^{127}$ Por. Proclus, In Platonis Rem publicam commentarii, ed. Kroll, II 144, 27 - 145, 14; tenże, In Timaeum Platonis commentaria, ed. Diehl, III 232, 29 - 233, 4.

${ }^{128}$ Por. też OH 62, 1 Do Dike, ed. Ricciardelli, s. 162.

${ }^{129}$ Por. OH 69 Do Erynii, ed. Ricciardelli, s. 176-178.

${ }^{130}$ Por. Mesomedes, Fragmenta, DAGM 28.

${ }^{131}$ Por. Julianus, Caesares 6, 310b, ed. Wright, II, s. 352.

${ }^{132}$ Por. OF 233.

${ }^{133}$ Por. Plutarchus Chaeronensis, De sera numinis vindicta 565A.

${ }^{134} \mathrm{Na}$ temat Dike i Pojnai w malarstwie wazowym zob. M.P. Nilsson, The Bacchic Mysteries of the Roman Age, HTR 46 (1953) 198-201.

${ }^{135}$ Por. Julianus, Misopogon 35, 362c, ed. Wright, II, s. 488; tenże, Oratio VII 22, 233d-234c, ed. Wright, II, s. 146-148. 
nie $^{136}$. Moim zdaniem odpowiedź brzmi nie, co uzasadniam w poniższym komentarzu. Hymn 2 nie ma wiele wspólnego z trzema hymnami homeryckimi ${ }^{137}$ - poza jednym wersetem (w. 13) (138 $^{138}$ ani też z orfickim hymnem do Afrodyty ${ }^{139}$.

Inwokacja (w. 1-3) do Afrogenei, czyli Zrodzonej z Piany, powinna pomóc w identyfikacji bogini, ale nie pomaga. Afrodyta pojawia się kilka- czy nawet wielokrotnie w systemie boskiej hierarchii Proklosa ${ }^{140}$. Epitet Afrogeneia (w. 1) odnosi się do aż dwu różnych Afrodyt: Afrodyty Uranii, córki wykastrowanego Uranosa i piany morskiej, oraz Afrodyty Dionaia, zrodzonej z nasienia Zeusa wytryśniętego w kierunku ściganej Dione i spadłego w morze ${ }^{141}$. Te dziwne wersje mitów, różne od klasycznych, Proklos zaczerpnął z Rapsodii orfickich ${ }^{142}$. Współczesny mu poeta Nonnos ${ }^{143}$ zna jeszcze dziwniejszy mit o Afrodycie Uranii, zrodzonej w Beroë (a nie na Cyprze) z nasienia Uranosa i piany morskiej przy pomocy Natury. Dziewicza bogini bezpośrednio po własnych narodzinach wydała na świat Erosa, który sam był własnym akuszerem i piastunem, a potem, gdy już opuścił łono matki, został ,pierwszym nasieniem, początkiem narodzin” ( Hymn $2 \mathrm{w}$ tym, że zrodzona z piany Afrodyta rodzi Erosy bez męża, podczas gdy Kurafrodyta Licyjska z Hymnu 5 jest ślubną żoną Hefajstosa.

W komentarzu do platońskiego Kratylosa 406c7-d2 Proklos uwzględnił obie Zrodzone z Piany Afrodyty, zarówno Uranię, jak i córkę Dione. Tekst ten jest kluczem do interpretacji Нутпи 2, więc przytaczam w całości:

„Boginie te różnią się od siebie co do początku, szeregu i mocy. Pierwsza z nich, zrodzona z Uranosa, jest boginią ponadświatową i anagogiczną: prowadzi ona wzwyż do noetycznego Piękna, wiedzie korowód nieskalanego życia, a od wcielenia oddziela. Ta druga natomiast, Dionaia (tj. córka Dione), zarządza światami niebieskim i ziemskim, wiąże je mocno ze sobą, a dzięki temu połączeniu doskonali ich postęp rozrodczy. Boginie łączą się nawzajem poprzez podobieństwo hipostaz, albowiem z mocy rozrodczej pochodzą obie: jedna Wiążącego, druga Demiurga. Morze w tym micie jest symbolem życia,

\footnotetext{
${ }^{136}$ Por. Van den Berg, Proclus' Hymns, s. 40 i 190-207.

${ }^{137}$ Por. Hymni Homerici 5, 6 i 10.

${ }^{138}$ Por. tamże 5 i 6.

${ }^{139}$ Por. OH 55, ed. Ricciardelli, s. 144-146.

${ }^{140}$ Por. T. Lankila, Aphrodite in Proclus' Theology, ,Journal for Late Antique Religion and Culture" 3 (2009) 21-43; zob. także tabela 1.

${ }^{141}$ Por. Proclus, In Platonis Cratylum commentaria 183, ed. Pasquali, 109, 21 - 111, 20.

${ }_{142}$ Por. OF 189, ed. Bernabé, fasc. 1, s. 169-170: „Jego [Uranosa] członek spadł z wysoka w morze, a wokół zebrała się biała piana. W cyklach pór rok zrodził wstydliwą dziewicę. Nowonarodzoną od razu wzięły na ręce Zazdrość i Odurzenie”; OF 260, ed. Bernabé, fasc. 1, s. 223-224: „Jeszcze większa ogarnęła go [Zeusa] żądza i z członka ojca wielkiego wytrysnęła płodna piana, a morze przyjęło nasienie wielkiego Zeusa. Gdy rok o pięknych porach zatoczył koło, zrodził Afrodytę, co śmiech budzi, Afrogeneię".

${ }^{143}$ Por. Nonnus Panopolitanus, Dionysiaca XLI 100-142, ed. Rouse, III, s. 202-206.

${ }^{144}$ Tamże XLI 129.
} 
które jedno tylko ma źródło, a z kolei głębia obrazuje rozlewanie się życia na wszechświat. Natomiast piana to coś najsubtelniejszego, pełnego płodnego światła i mocy, skąd życie się rozwija, jak kwiat z pąka"145.

Cytowany tekst wyjaśnia relacje między dwiema Afrodytami i stanowi doskonałe uzupełnienie Hymnu 2. Adresatka hymnu, określona jako „łańcuch Afrogenei” (w. 1) i ,wielkie źródło królewskie” (w. 2) to córka Uranosa, przełożonego Wiążących z enneady noetyczno-noerycznej, która odpowiada za życie (por. III 4-6 w tabeli 1). Bogini ta plasuje się znacznie niżej od swego ojca, bo pojawia się dopiero w momencie pocięcia go przez Kronosa ${ }^{146}$, jako siódma i ostatnia z Wielkich Demiurgów (por. IV 7 w tabeli 1). W systemie Proklosa orficka Urania odpowiada chaldejskiej „noerycznej membranie” i „Kwiatowi Ognia”"147, stąd filozof nazywa ją „Kwiatem Życia” w cytowanym tekście. Funkcją bogini jest oddzielanie od siebie porządków wyższych i niższych, a w przypadku dusz ludzkich - zniechęcanie ich do inkarnacji i kierowanie zawsze wzwyż, ku boskiemu Pięknu. Hipostazą Uranii jest Afrodyta, córka Demiurga Zeusa i Dione, której Proklos poświęcił drugi hymn - Hymn 5. Ta bogini, uplasowana znacznie niżej w hierarchii (por. VI $11 \mathrm{w}$ tabeli 1), także działa anagogicznie, ale w przeciwieństwie do swej poprzedniczki, patronuje również życiu w aspekcie ziemskim, czyli małżeństwom, rozmnażaniu się, wcielaniu. Obie Afrodyty działają w świecie komplementarnie, jakby były jedną boginią. Należą przecież do tego samego łańcucha (por. w. 1 i 18).

Aretologia (w. 4-13) odpowiada w treści podziałowi na córkę Uranosa i córkę Dione, $\mathrm{z}$ tym, że sama Afrodyta została zastąpiona przez Erosy, które z niej wyleciały (w. 3). Erosy dzielą się na trzy grupy. Pierwsze są ewidentnie dziećmi Uranii, bo odpowiadają za ruch wzwyż, tak jak ona, wyprowadzają dusze z ciał i pomagają im wrócić na „dwór matki” (w. 5-6). Drugie, które muszą być dziećmi Afrodyty Dionaia, kierują ruchem w dół, ku światu, ziemi i wcieleniu (w. 7-9). I wreszcie rodzaj trzeci jest czymś pomiędzy pierwszymi i drugimi, ponieważ poprzez zawieranie małżeństw, którym patronuje, stara się wyhodować „nieśmiertelną rasę” z ludzi żyjących na ziemi (w. 10-12).

${ }^{145}$ Proclus, In Platonis Cratylum commentaria 183, ed. Pasquali, 111, 6-20.

${ }^{146}$ Por. Proclus, In Platonis Rem publicam commentarii, ed. Kroll, I 82, 16-20.

${ }^{147}$ Por. OC 6, ed. Majercik, s. 50: „oddziela tak jak noeryczna membrana jeden ogień od drugiego ognia, które chcą się połączyć”; tamże 34, ed. Majercik, s. 60: „Stąd wytrysnęły narodziny różnorakiej materii, stąd powłóczysty grot piorunu, który przesłania Kwiat Ognia i wnika w zakamarki świata, stąd biorą się wszystkie cudowne promienie, które świecą na świat poniżej"; tamże 35, ed. Majercik, s. 60: „Z Ojca wytryskają twarde groty piorunów oraz przyjmujące je łona świetlistego blasku zrodzonej z Ojca Hekate; ponadto opasujący Kwiat Ognia i potężne Pneuma za słupami żaru”; tamże 37, ed. Majercik, s. 62: „Źródło jedyne, źródło ojcowskie, z którego wylatują z poszumem noeryczne myśli. Jedne z nich dzielą się i rozpryskują na ogromne ciała kosmiczne, inne wirują wokół straszliwych łon, rozświetlają je, nieustannie i niestrudzenie niczym rój pszczół spijają Kwiatu Ognia. Pierwsze źródło Ojca wytryska samo z siebie, a z niego z kolei pierwotne idee”; tamże 38, ed. Majercik, s. 62: „To są myśli Ojca, a poniżej mój otaczający ogień”. Wszystkie fragmenty, oprócz OC 6, są cytatami z Proklosa. 


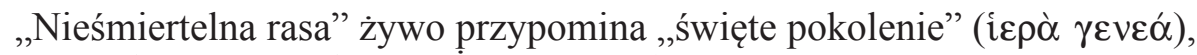
o którym pisze Damascjusz w Żywocie Izydora:

„Święte pokolenie w odosobnieniu wiodło życie bogom miłe i szczęśliwe, filozofowało i boskie kultywowało rytuały"148.

Tym świętym pokoleniem byli oczywiście neoplatonicy, którzy żenili się między sobą i żyli jak rodzina ${ }^{149}$. Biograf Marinos podaje, że Proklos tytułował Syrianosa, diadocha Akademii, u którego studiował, swoim ojcem, a jego nauczyciela, Plutarcha z Aten - swoim dziadkiem ${ }^{150}$. Kazał się pochować razem z Syrianosem i ułożył wspólne epitafium, które Marinos cytuje:

„Ja jestem Proklos rodem z Licji, którego Syrianos

Wychował na swego następcę.

Ten oto grób przyjął ciała nas obu.

Oby dusze nasze wspólną miały siedzibę!"151.

Co więcej, Proklos miał poślubić krewną Syrianosa, by wszystko zostało w rodzinie, ale z niewiadomych powodów odmówił i wolał resztę życia spędzić w celibacie (por. Komentarz do Hymnu 7). Święta rasa neoplatoników ucieleśniała, jak pisze Damascjusz ${ }^{152}$, „mityczne życie Kronosa” ( $\mu v \theta \varepsilon v o ́ \mu \varepsilon v o \varsigma$ Kpóvıs ßíos), czyli srebrny wiek ludzkości.

Inwokacja i modlitwa (w. 14-21) zaskakują z dwóch powodów. Po pierwsze, niższa Afrodyta (wymieniona jako „bogini”) zostaje utożsamiona z Duszą Świata (w. 16). Sam Proklos był odmiennego zdania, identyfikując Duszę Świata z rozerwanym na strzępy Dionizosem i jego nianią Hiptą (zob. VII 1b w tabeli 1) ${ }^{153}$, wobec czego dystansuje się od tego pomysłu poprzez ,jak mówią" (w. 15). Skąd pochodził ten pogląd? Plotyn w traktacie O Erosie ${ }^{154}$ interpretował Afrodytę, córkę Dione, jako Duszę Świata, tak więc Proklos powołuje się na opinię samego Plotyna. Gdzie indziej Proklos cytuje wersety Wyroczni chaldejskich ${ }^{155}$, które pierwotnie odnosiły się do Hekate, generującej z siebie Duszę Świata, ale nie wymienia imiennie żadnej bogini ${ }^{156}$. Z Hym-

${ }^{148}$ Damascius, Vita Isidori fr. 95, ed. Zintzen, s. 140.

${ }^{149}$ Por. Athanassiadi, Persecution and Response in Late Paganism, s. 5-7.

${ }^{150}$ Por. Marinus Neapolitanus, Vita Procli 29, ed. Masullo, s. 86.

${ }^{151}$ Tamże 36, ed. Masullo, s. 92 = Anthologia Graeca VII 341, ed. W.R. Paton: The Greek Anthology, II, London 1919, Loeb, 184.

${ }^{152}$ Por. Damascius, Vita Isidori fr. 33, ed. Zintzen, s. 31 = OF 217.

${ }^{153}$ Por. OF 329.

${ }^{154}$ Por. Plotinus, Enneades III 5, 2, éd. É. Bréhier: Plotin, Ennéades, I-VI, Paris 1924-1938, Les Belles Lettres, tutaj: III, s. 76-78, thum. A. Krokiewicz: Plotyn, Enneady, I, Warszawa 2000, AKME, 291.

${ }^{155}$ Por. OC 51, ed. Majercik, s. 68: „W prawym zagłębieniu koło zbiornika z ziarnem tryska obfite źródło duszy - początku narodzin, ożywiające światło, ogień, eter i światy"; tamże 53, ed. Majercik, s. 68: „Ja, Dusza, która swoim ciepłem ożywiam wszystko, mieszkam niżej niż myśl Ojca”.

${ }^{156}$ Por. Proclus, In Platonis Rem publicam commentarii, ed. Kroll, II 201, 10-16; tenże, In Timaeum Platonis commentaria, ed. Diehl, II 61, 22-25. 
nem 2, w. 15-17 dobrze koresponduje deklaracja „Afrodyta jest wszędzie”, wyrażona przez Proklosa w Komentarzu do „Państwa” Platona ${ }^{157}$.

Po drugie, zaskakujące jest zakończenie (w. 20-21): nie, dziękuję, nie chcę się wcielać nigdy więcej, jeśli nawet Erosy przynoszą czasem coś dobrego i zamierzają wyhodować z ludzi jakąś wyższą rasę. Żądze są „lodowate” (w. 21), odwrotnie niż w polskiej frazeologii, ponieważ prowadzą do wcielenia, które Proklos wyobraża sobie jako zimne, huczące morze (por. Hymn 3, w. 8-14, Hymn 4, w. 10-12, Hymn 6, w. 10-12).

\section{Hymn 3}

Hymn do Muz wymaga krótkiego wprowadzenia w platoński mit o reinkarnacji. Platon podzielał orfickie i pitagorejskie wierzenia o wędrówce duszy - upadłego z nieba dajmona, który jest w ciele gościem, a właściwie więźniem $^{158}$. Wszystkie dusze, jak twierdził ${ }^{159}$, raz na 10 tysięcy lat pasą się na Łące Prawdy, gdzieś wysoko nad niebem, by następnie na skrzydłach pamięci wrócić ze swym bogiem-archontem i pełnić rolę opatrzności w świecie. Jednakże niedożywione dusze pewnych dajmonów, które nie zdołały zapuścić skrzydeł, muszą spadać na ziemię i wcielać się w ludzi lub zwierzęta. Po dziewięciu wcieleniach i upływie dziesięciu tysięcy lat, gdy Rok Kosmiczny zatoczy koło, wracają na Równinę Prawdy i znowu się pasą. Czas przymusowych inkarnacji jest bardzo długi, ale możliwa jest wcześniejsza amnestia dla dusz, które trzykrotnie wybrały żywot filozofa. Filozofom odrastają skrzydła, symbol pamięci, już po trzech tysiącach lat, tak że mogą odlecieć do swego patrona Zeusa ${ }^{160}$, do pokrewnej gwiazdy ${ }^{161}$ albo do ulubionej Muzy: Kaliope bądź Uranii ${ }^{162}$. Platon szczególnie czcił Muzy, patronki filozofii i pamięci, a w centrum Akademii wzniósł Muzejon na ich cześćc ${ }^{163}$.

Inwokacja (w. 1-2) do dziewięciu córek Zeusa przypomina wersety homeryckie ${ }^{164}$, w których poeta prosi, by Muzy dopomogły jego pamięci. W swym Komentarzu do „Kratylosa" 165 Proklos podporządkował te boginie Apollonowi Muzagetesowi ${ }^{166}$ i dowodził, że ich liczba, dziewięć, symbolizuje harmonię duchową i że cała dziesiątka to bóstwa anagogiczne, czyli pozwalające duszy

\footnotetext{
${ }^{157}$ Por. Proclus, In Platonis Rem publicam commentarii, ed. Kroll, I 141, 21.

${ }^{158}$ Por. OF 421-469.

${ }^{159}$ Por. Plato Phaedrus 248c-249a = OF 459.

${ }^{160}$ Por. Plato Phaedrus 246e-247a.

${ }^{161}$ Por. Plato, Timaeus 42b.

${ }^{162}$ Por. Plato, Phaedrus 258e-259d = 49F2, ed. G.J. van Dijk: Ainoi, Logoi, Mythoi: Fables in Archaic, Classical, and Hellenistic Greek Literature, Leiden 1997, Brill, 327-330.

${ }^{163}$ Por. Diogenes Laertius, Vitae philosophorum IV 1 i 19, ed. M. Marcovich, I, Berlin 2008, Gruyter, 256 i 271.

${ }^{164}$ Por. Homerus, Ilias II 484-493.

${ }^{165}$ Por. Proclus, In Platonis Cratylum commentaria 176-177, ed. Pasquali, 100,11 - 103,23.

${ }^{166}$ Por. Hymni Homerici 25.
} 
wznieść się ponad ten świat i odzyskać utraconą prostotę i doskonałość. Związek z Apollonem i epitet ,anagogiczne światło” (Hymn 3, w. 1) pozwalają zaliczyć Muzy do triady anagogicznej, na której czele stoi Hermes i której Apollon jest członkiem (por. VI 12 w tabeli 1). W takim razie, Muzy byłyby ogniwami tego samego ,łańcucha hermetycznego", do którego należeli, wedle wierzeń neoplatońskich, wszyscy wybitni filozofowie ${ }^{167}$.

Aretologia (w. 3-9) określa najważniejszą dla Proklosa funkcję tych bogiń, różną od tej, którą przypisali im Homer i Platon. Otóż pomagają one, jak mówi tekst, „Szybko” (w. 6) przerwać koszmar narodzin. Co to znaczy „szybko”? Dla Platona ${ }^{168}$ i Empedoklesa ${ }^{169}$ były to minimalnie trzy tysiące lat, w czasie których dusza wcielała się trzy razy (Platon) lub dziesięć razy (Empedokles), a czas pomiędzy inkarnacjami spędzała gdzieś w niebie albo w Hadesie ${ }^{170}$. Natomiast przeciętny okres wygnania wynosił dziesięć tysięcy lat ${ }^{171}$, zaś karne zesłanie za ciężkie grzechy - aż trzydzieści tysiącleci ${ }^{172}$.

Największym zagrożeniem dla dusz i tym, co mogło przedłużyć ich ziemską odyseję, były wody Lete, czyli Niepamięci (w. 6) ${ }^{173}$. Muzy pomagały przezwyciężyć tę tendencję poprzez święte księgi i wtajemniczenia w misteria (w. 5). Kojarzenie Muz ze świętymi księgami nie może dziwić, skoro boginie te patronowały poszczególnym działom literatury, a z kolei ich związek z misteriami był czymś równie oczywistym, co związek z Apollonem ${ }^{174}$. Bezcelowe jest dociekanie, jakie święte księgi i misteria ma na myśli autor. Brak w tym hymnie wskazówek pozwalających na wiązanie ich z orfizmem, jak chce Van den Berg ${ }^{175}$, który na moment zapomina o Wyroczniach chaldejskich.

${ }^{167}$ Por. Marinus Neapolitanus, Vita Procli 28, ed. Masullo, s. 85: „Pewnego razu przyśniło mu się, że ma duszę pitagorejczyka Nikomacha. Uwierzył, że należy do łańcucha hermetycznego"; Proclus, Theologia Platonica VI 22, ed. Saffrey - Westerink, V 98, 14-24: „Z triady anagogicznej Hermes jest przywódcą filozofii; dlatego właśnie dusze wzwyż prowadzi i poprzez zdolności dialektyczne odsyła je wszystkie razem i każdą z osobna do samego Dobra. Dalej Afrodyta jest pierwszą przyczyną miłosnego natchnienia, co wszystkie rzeczy przenika, i zapoznaje z Pięknem te wszystkie życia, które ma w swej pieczy. Apollon muzyką wszystko doskonali, naprawia i razem spaja, jak mówi Sokrates, a dzięki harmonii i rytmowi ku noerycznej ciągnie Prawdzie i Światłu, które jest tam. Ogólnie powiedzieć możemy, że bogowie, którzy znajdują się ponad bóstwami kosmicznymi, spajają cały chór niewcielonych dusz, bo zdolności noeryczne i twórcze tychże zależą właśnie od nich".

168 Por. Plato, Phaedrus 249a = OF 459.

${ }^{169}$ Por. Empedocles, Fragmenta 31 B 146, ed. H. Diels - W. Kranz: Die Fragmente der Vorsokratiker, I-III, Berlin 1951-19526.

${ }^{170}$ Por. Plato, Phaedrus 249a.

${ }^{171}$ Por. tamże $248 \mathrm{~b}=$ OF 459.

172 Por. Empedocles, Fragmenta 31 B $115=$ OF 449.

${ }^{173}$ Por. Plato, Phaedrus 248c; OH 77, 3. 10 Do Mnemosyne, ed. Ricciardelli, s. 194; Marinus Neapolitanus, Vita Procli 5, ed. Masullo, s. 62.

${ }^{174}$ Por. OH 76, 7 Do Muz, ed. Ricciardelli, s. 192, tłum. Żybert, s. 102; Mesomedes, Fragmenta, DAGM 25.

175 Por. Van den Berg, Proclus'Hymns, s. 212. 
Celem pokonania wód Lete jest powrót do „pokrewnej gwiazdy” (w. 7) motywu platońskiego ${ }^{176}$, który Proklos gdzie indziej ${ }^{177}$ interpretował w sensie astrologicznym jako sfery planet Saturna, Jupitera, Słońca i Księżyca, a prócz tego motywu popularno-magicznego ${ }^{178}$. Logicznym uzupełnieniem ,pokrewnej gwiazdy" jest modlitwa o „święte światło”, która następuje w w. 15. Obraz Muz, które ratują zbłąkaną duszę z fal narodzin i wiodą ku światłości, występuje w zacytowanej przez Porfiriusza wyroczni, udzielonej przez Apollona Delfickiego o Plotynie ${ }^{179}$. Pośpieszny powrót do światła, ale bez pomocy Muz, pojawia się w Wyroczniach chaldejskich ${ }^{180}$.

Modlitwa (w. 10-17) koncentruje się na temacie reinkarnacji. Poeta prosi dziewięć bogiń o rzeczy, które uważa za istotne: sławę (w. 17), uwolnienie od żądz (w. 10), szał bachiczny (w. 11), miód ze świętych uli (w. 16), wskazanie świętej ścieżki (w. 13), obronę przed atakami bezbożników (w. 12) i wreszcie o najważniejsze - wyłowienie z huczących fal narodzin (w. 14-15).

„Szał bachiczny” nie oznacza tu intoksykacji czy upojenia winem, ale stan ciała i umysłu, w którym znajduje się człowiek inicjowany w misteria. Osobę taką zwano „bachusem” i termin ten miał często wydźwięk tyleż mistyczny, co intelektualny ${ }^{181}$. „Ule” stanowią czytelną aluzję do znanego wyobrażenia poetów lub filozofów jako świętych pszczół, które spijają miód z kwiatów rosnących w ogrodach Muz ${ }^{182}$. Według Porfiriusza ${ }^{183}$ miód świętych pszczół jest nektarem, ekstatycznym trunkiem bogów, używanym w czasach przed wynalezieniem wina. „Święta ścieżka” to oczywiście droga do Boga, przy której rosną dobra kontemplacyjne ${ }^{184}$. „Bezbożnikami” są jak zwykle chrześcijanie, do których subtelne przytyki znajdują się także w Hymnach 1, w. 41 i 7, w. 50.

Tok rozumowania wydaje się mniej więcej taki: skoro filozofia jest tym, co przerywa cykl wcieleń przed upływem 10 tysięcy lat, to tylko Muzy, patronki filozofii, zdolne są uwolnić duszę z tego więzienia.

${ }^{176}$ Por. Plato, Timaeus 42b.

${ }^{177}$ Por. Proclus, In Timaeum Platonis commentaria, ed. Diehl, III 261, 12 - 263, 22 i 290, 18-28.

${ }^{178}$ Por. PGM IV 574: „Ja jestem gwiazdą, która razem z wami błąka się i świeci z otchłani”.

179 Por. Porphyrius, Vita Plotini 22, 13-63, éd. Bréhier, I, s. 25-26, tłum. Krokiewicz, I, s. 82-83.

${ }^{180}$ Por. OC 115, ed. Majercik, s. 92: „Trzeba się spieszyć do światła i do promieni Ojca, skąd została wysłana twoja dusza, odziana w wielki intelekt".

${ }^{181}$ Por. OF 576 = Plato, Phaedo 69d1: ,Wielu nosi tyrsy, niewielu zostaje bachusami”; Marinus Neapolitanus, Vita Procli 22, ed. Masullo, s. 78: „Albowiem Proklos oczyścił się już i przezwyciężył przymus wcielenia, wzniósł się ponad zwykłe noszenie tyrsu, stał się pierwszym bachusem i na własne oczy oglądał błogosławione widoki z tamtego świata, dane tylko wtajemniczonym”; Damascius, Vita Isidori fr. 163, ed. Zintzen, s. 137, thum. pol. w nocie 39.

${ }^{182}$ Por. Plato, Ion 534b; Proclus, In Platonis Rem publicam commentarii, ed. Kroll, II 1, 1-12.

${ }^{183}$ Por. Porphyrius, De antro nympharum 15-19, ed. L. Simonini: Porfirio, L'antro delle Ninfe, Milan 1986, 56-64.

${ }^{184}$ Por. Julianus, Oratio VII 22, 230d, ed. Wright, II, s. 138; Proclus, Theologia Platonica IV 17, ed. Saffrey - Westerink, IV 51, 10-12. 


\section{Hymn 4}

Hymn do anonimowych bogów ma niezwykłą budowę: trzy części, na które się rozpada (w. 1-4, 5-12, 13-15), zaczynają się każda od krótkiej inwokacji, by od razu przejść w modlitwę. Wersy 1 i 13 są bardzo podobne (ale nie identyczne) pod względem doboru słów i treści.

Spory problem dla uczonych przedstawia tożsamość bogów tego hymnu, ponieważ nie padają w nim konkretne imiona. Badacze argumentują albo za „Wszystkimi bogami”, do których Proklos odnosi się we wstępach do Teologii Platońskiej i Komentarza do „Parmenidesa"185, albo za identyfikacją z bóstwami Wyroczni Chaldejskich ${ }^{186}$. R.M. Van den Berg opowiada się za pierwszą opcją ${ }^{187}$. Oba poglądy, jak wykazuję niżej, są nie do utrzymania.

Inwokacje (w. 1-2, 5a, 13-14) udzielają wystarczająco dużo wskazówek, by umożliwić identyfikację „bogów”. Są oni określani jako: „przewodnicy mądrości” (w. 1 i 13), ,wielcy zbawiciele” (w. 5) i ,anagogiczny ogień” (w. 2, thumaczę wyżej „wzniosły ogień”). Dane te zestawione z dwoma tekstami Teologii Platońskiej o czwartej triadzie bogów olimpijskich ${ }^{188}$ oraz o hierarchii cnót ${ }^{189}$ dają pełną podstawę do wniosku, że „bogami” z hymnu jest triada anagogiczna bogów olimpijskich, czyli Hermes, Afrodyta i Apollon (por. pozycje VI 10-12 w tabeli 1). Proklos poświęcił dwa inne hymny (Hymny 3 i 5) bogom z tejże triady.

Według Teologii Platońskiej Hermes jest przywódcą filozofii i prowadzi dusze do Dobra, Afrodyta - patronka miłości wiedzie je ku Pięknu, a z kolei Apollon, przewodnik Muz, swoją muzyką wznosi je do Prawdy i Światła.

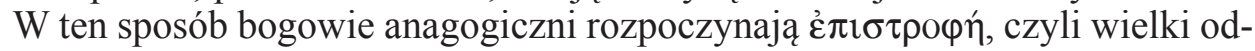
wrót od świata widzialnego w kierunku Jedna ${ }^{190}$. Zbawiają oni cały świat poprzez boskie cnoty: Mądrość, Dobro i Piękno, wymienne czy prawie wymienne z chaldejską triadą cnót: Wiarą, Prawdą i Miłością ${ }^{191}$, które z kolei prowadzą na jeszcze wyższy poziom, do Sprawiedliwości, Wiedzy i Samokontroli,

${ }^{185}$ Por. Proclus, Theologia Platonica I 1, ed. Saffrey - Westerink, I 6, 16 - 7, 8; Proclus, In Platonis Parmenidem I Prol. 1, 617, ed. Steel, I, s. 1.

${ }^{186}$ Zob. przegląd literatury w: Van den Berg, Proclus'Hymns, s. 224-227.

${ }^{187}$ Por. tamże, s. 225.

${ }^{188}$ Por. Proclus, Theologia Platonica VI 22, ed. Saffrey - Westerink, VI 98, 14-24.

${ }^{189}$ Por. tamże I 25, ed. Saffrey - Westerink, I 109, 4 - 113, 10.

${ }^{190}$ Proclus, Theologia Platonica VI 22, ed. Saffrey - Westerink, VI 98, 14-24: „Z triady anagogicznej Hermes jest przywódcą filozofii; dlatego właśnie dusze wzwyż prowadzi i poprzez zdolności dialektyczne odsyła je wszystkie razem i każdą z osobna do samego Dobra. Dalej Afrodyta jest pierwszą przyczyną miłosnego natchnienia, co wszystkie rzeczy przenika, i zapoznaje z Pięknem te wszystkie życia, które ma w swej pieczy. Apollon muzyką wszystko doskonali, naprawia i razem spaja, jak mówi Sokrates, a dzięki harmonii i rytmowi ku noerycznej ciągnie Prawdzie i Światłu, które jest tam. Ogólnie powiedzieć możemy, że bogowie, którzy znajdują się ponad bóstwami kosmicznymi, spajają cały chór niewcielonych dusz, bo zdolności noeryczne i twórcze tychże zależą właśnie od nich".

${ }^{191}$ Por. OC 46, ed. Majercik, s. 66. 
będącymi domeną Niewidzialnych Nocy. Do boskich cnót ludzie wspinają się mozolnie po szczeblach miłości, filozofii i muzyki albo teurgii ${ }^{192}$. A wspinać się warto, ponieważ nagrodą jest uwolnienie od klątwy reinkarnacji.

Tabela 2. System cnót według Proklosa

\begin{tabular}{llll} 
Stopnie bytów & \multicolumn{2}{c}{ Cnoty } \\
Niewidzialne Noce & Sprawiedliwość & Wiedza & Samokontrola \\
Bogowie wyżsi & Dobro & Mądrość & Piękno \\
Bogowie niżsi & Wiara & Prawda & Miłość \\
Ludzie & Teurgia/muzyka & Filozofia & Miłosny szał \\
$\begin{array}{l}\text { Patroni }= \\
\text { bogowie anagogiczni }\end{array}$ & Apollon & Hermes & Afrodyta
\end{tabular}

Tak więc nie ma powodu, by przez „bogów” z Hymnu 4 rozumieć panteon, skoro sam tekst zawęża ich do bogów anagogicznych. Hermes, Afrodyta i Apollon na pewno nie są bogami wyłącznie chaldejskimi (czyli patronami sfer planetarnych Merkurego, Wenus i Słońca), bo ich imiona występują u Proklosa pośród dwunastki bogów olimpijskich, a ta jest przecież klasycznie grecka.

Modlitwy (w. 3-4, 5b-12, 15) nasuwają trzy problemy interpretacyjne: jak rozumieć święte światło, natchnione księgi, misteria, mity i hymny. W tym miejscu powracamy do alternatywy: orfickie czy chaldejskie. Czy „natchnione księgi" wymienione w w. 5 są to Rapsodie orfickie czy Wyrocznie chaldejskie? Akademia Platońska w tym okresie, gdy Proklos studiował u Syrianosa (430437), pasjonowała się na równi Rapsodiami orfickimi, co Wyroczniami chaldejskimi. Proklos znał na pamięć jedne i drugie; Wyrocznie chaldejskie były jego konikiem i przez pięć lat pisał komentarze do nich ${ }^{193}$. Jednakże nie należy

${ }^{192}$ Tu Proklos nie może się zdecydować, zob. Theologia Platonica I 25, ed. Saffrey - Westerink, I 109, 4 - 113, 10.

${ }^{193}$ Por. Marinus Neapolitanus, Vita Procli 26, ed. Masullo, s. 82 = OF 677ii: „Proklos posiadł te cnoty, gdy studiował u Syrianosa, gdy pod jego kierunkiem czytał starożytnych filozofów, gdy z ust swego nauczyciela spijał zapładniające krople orfickiej i chaldejskiej teologii. Ale Proklos nigdy nie znalazł czasu na napisanie komentarza do poezji Orfeusza. Syrianos miał zamiar sporządzić komentarz do pism orfickich albo do Wyroczni chaldejskich; pozostawił wybór Proklosowi i Domninosowi, filozofowi z Syrii i diadochowi, co będą komentować. Ale oni nie mogli się zgodzić: Domninos wybrał poematy orfickie, Proklos - Wyrocznie chaldejskie. Przeszkodziło to wielkiemu Syrianosowi w rozpoczęciu pracy, a potem umarł. Jednakowoż, jak powiedziałem, otrzymał podstawowe wytyczne od swego mistrza, a ponadto wnikliwie studiował jego komentarze do Orfeusza, a także wielotomowe dzieła Porfiriusza i Jamblicha o Wyroczniach i o towarzyszących pismach Chaldejczyków. Odżywiony boskimi wyroczniami, wspiął się, na ile człowiek potrafi, na wyżyny cnót, które boski Jamblich nazywał w swój natchniony sposób teurgicznymi. Krytycznie zestawiał i porównywał komentarze poprzednich filozofów, zebrał też inne chaldejskie traktaty i największe komentarze do natchnionych Wyroczni. Praca ta zajęła mu całych pięć lat"; tamże 27, ed. Masullo, s. 84 = OF 677xii: „Pewnego dnia czytaliśmy z Proklosem pisma orfickie, i słuchaliśmy jego ko- 
zapominać o pozostałych pismach należących do tzw. Biblii pogańskiej, mianowicie poematach Homera i Hezjoda, pismach gnostyckich i Corpus Hermeticum. Dlaczego Proklos, hierofanta świata, miałby ignorować wszystko inne poza Wyroczniami chaldejskimi? Dlaczego „natchnione księgi” nie mogłyby być na przykład dialogami ukochanego Platona?

Pod względem stylistycznym i werbalnym Hymn 4 najbardziej przypomina Hymny orfickie. „Raczcie wysłuchać” ( $\kappa \lambda \hat{v} \tau \varepsilon$ i $\kappa \varepsilon ́ \kappa \lambda \nu \tau \varepsilon)$ w w. 1, 5 i 14 to powracająca formuła inwokacyjna Hymnów orfickich ${ }^{194}$, „święte światło" ( $\varphi$ óoৎ

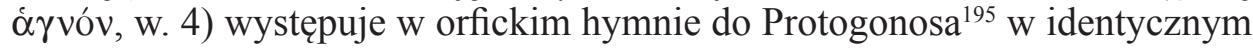
sformułowaniu, nie licząc wielu podobnych ${ }^{196}$. Wyrocznie chaldejskie ${ }^{197}$ nie mają monopolu na „ogień”, bo ten wyraz znajdzie się w literaturze orfickiej ${ }^{198}$, nie mówiąc już o ,wielkim ogniu" z Eleusis ${ }^{199}$. Wreszcie terminologia miste-

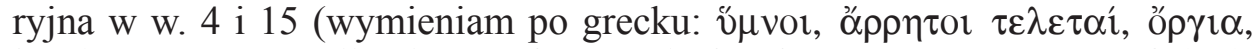
iعpoì $\mu \hat{v} \theta$ or) przewija się w zakończeniu każdego z 87 Hymnów orfickich. Czy zatem paralele orfickie nie przeważają nad tymi nielicznymi i wcale nie oczywistymi aluzjami do Wyroczni chaldejskich, które analizuje Van den Berg w swoim komentarzu ${ }^{200}$ ? Nie znaczy to, bynajmniej, że inicjacje, do których przygotowuje się autor, musiały być misteriami orfickimi. Mogły to być każde inne: Hekate, Dionizosa, Mitry, Kybele czy Eleusis.

Hymn 4 informuje swego czytelnika, od czego mają go zbawić ,wielcy zbawiciele”, mianowicie od zła największego z możliwych: od nieszczęścia narodzin i uwięzienia w ciele (w. 3, 8-12). Wody narodzin i ich straszna bogini Pojne, czyli „Kara”, są zimne czy wręcz lodowate (w. 10 i 12) dla kontrastu z boskim żarem i świętym światłem (w. 2 i 6), podobnie jak w hymnie do Ojca - Pierwszego Ognia, cytowanym wyżej. Proklos ma zawsze ten sam pełen dezaprobaty stosunek do życia doczesnego ${ }^{201}$, w czym nie różni się zresztą od innych neoplatoników ${ }^{202}$. Zmierzanie wzwyż, w górę (w. 14) jest najważ-

mentarzy. Powoływał się nie tylko na Jamblicha i Syrianosa, lecz także wielu innych, którzy badali ich głęboką teologię. Poprosiłem wtedy wielkiego filozofa, by ułożył pełny komentarz do pism orfickich. Odpowiedział mi, że miał taki zamiar, ale zrezygnował przez pewne sny. Zobaczył we śnie swego nauczyciela Syrianosa, który kategorycznie mu tego zabronił. Wymyśliłem więc, że mógłby zrobić wyciąg z komentarzy swego mistrza do Orfeusza. Zgodził się dopisać noty na marginesach rękopisu Syrianosa. Tym sposobem mamy jego scholia i komentarze do kilku wierszy, choć nie do całych Rapsodii".

${ }^{194}$ Por. OH 59, 2; 60, 1; 69, 1; 70, 1 i inne.

${ }^{195}$ Por. OH 6, 8, ed. Ricciardelli, s. 22.

${ }^{196}$ Por. OH 3, 10; 8, 2, 18; 43, 8; 78, 13 i inne.

${ }^{197}$ Por. OC 5-6, 10, 32-35, 42, 126, 130 i 148.

${ }^{198}$ Por. np. OF 31.5, 243.8 i 603.

${ }^{199}$ Por. m.in. Clemens Alexandrinus, Protrepticus II 22, 1, ed. M. Marcovich, Leiden, 1995, Brill, 31.

${ }^{200}$ Por. Van den Berg, Proclus' Hymns, s. 229-237.

${ }^{201}$ Por. Proclus, In Timaeum Platonis commentaria, ed. Diehl, III 325, 12-13.

${ }^{202}$ Por. Porphyrius, Vita Plotini 22, 24-34, éd. Bréhier, I, s. 25, tłum. pol. Krokiewicz, I, s. 8283; Synesius Cyrensis, Hymnus 9(1), 102-107, éd. Lacombrade, s. 104: „Nawet w upadłych tutaj 
niejszym celem duszy, w którym pomagają jej właśnie bogowie anagogiczni, odpowiedzialni za postęp duchowy. Najbardziej tajemniczy w tym hymnie jest w. 7 („,Bym zdołał rozpoznać nieśmiertelnego boga i człowieka”) - daleka reminiscencja Homera ${ }^{203}$, która brzmi jak formuła chrystologiczna.

Wymienione drogi zbawienia to księgi (w. 5), mity (w. 15), hymny (w. 4) i misteria (w. 4 i 15). Interesującym pendant do „misteriów hymnów” (w. 4) są Hymny metryczne Synezjusza z Cyreny, który uważa, że śpiewanie hymnów trzy razy dziennie wzmacnia kondycję skrzydeł duszy, a z kolei skrzydła pomagają w ucieczce $\mathrm{z}$ tego świata ${ }^{204}$. W ogóle Synezjusz i Proklos wydają się wierzyć w oczyszczającą moc literatury: ksiąg, mitów i hymnów, w to, że „Święte słowa” mogą zastąpić dawne ofiary i misteria.

\section{Hymn 5}

Hymn do Afrodyty z Licji porusza wątki autobiograficzne i jest jedynym, w którym Proklos nie drąży tematu reinkarnacji.

Prolog (w. 1) „Hymn śpiewam na cześć Kurafrodyty, królowej Licji” określa adresatkę hymnu - lokalną boginię z Azji Mniejszej. Rodzina Proklosa pochodziła z Licji ${ }^{205}$, dokładnie z miasta Ksanthos. On sam urodził się w Konstantynopolu, ale wkrótce potem rodzice Patrycjusz i Marcella odesłali go do Ksanthos, aby tam się wychował i odebrał pierwsze nauki.

Przydomek kultowy „Kurafrodyta” to hapaks w greckiej literaturze, niepoświadczony w inskrypcjach. Afrodyta z Licji - bo o to bóstwo przecież chodzi - pojawia się w dwu inskrypcjach napisanych alfabetem i językiem licyjskim. Pierwsza z nich, chronologicznie wcześniejsza (dat. koniec V wieku przed Chr.) to słynna stela kamienna, ufundowana na cześć miejscowej dynastii i ustawiona na agorze w Ksanthos ${ }^{206}$. Tekst w języku licyjskim wymienia wiodące bóstwa tego miasta: Maliya czyli Atena ${ }^{207}$, Ertemi czyli Artemida ${ }^{208}$, Trqqas czyli Zeus ${ }^{209}$ i Padrita czyli Afrodyta ${ }^{210}$. Ta sama bogini pojawia się na fryzie metalowego naczynia z British Museum (dat. 350-300 przed Chr.),

został jakiś anagogiczny popęd, gdy przed falami uciekłszy życia, beztrosko na święte zapuszczają się szlaki ku pałacowi rodzica”; tenże, Hymnus 7(8), 42-47, éd. Lacombrade, s. 91-92: „Duszę moją wyrwij z ziemskich kajdan! Uwolnij od bólu i ziemskiej tułaczki! Pozwól mi wznosić hymny ze świętym chórami na cześć Twego Ojca, na Twoją cześć".

${ }^{203}$ Por. Homerus, Ilias 22, 9.

${ }^{204}$ Por. Synesius Cyrensis, Hymnus 2(4), 283-285, éd. Lacombrade, s. 67. O tym, że hymny miały być śpiewane trzy razy dziennie, por. wyżej nota 36 .

${ }^{205}$ Por. Proclus, Hymnus 5, 13; zob. Marinus, Vita Procli 6, 8 i 36.

${ }^{206}$ Por. Tituli Lyciae lingua Lycia conscripti 44, ed. E. Kalinka, Vindobonae 1901, Hoelderli.

${ }^{207}$ Por. tamże 44 c26.

${ }^{208}$ Por. tamże $44 \mathrm{c} 8$.

${ }^{209}$ Por. tamże 44 c30.

${ }^{210}$ Por. tamże 44 b53; zob. E. Payne, Lycia - Crossroads of Hittite and Greek Traditions, w: E. Cingano - L. Milano, Papers on Ancient Literatures: Greece, Rome and Near East, Padova 2008, SARGON, 471-488. 
który przedstawia sąd Parysa. Boginie Atena i Afrodyta zostały wyobrażone w greckich szatach i podpisane licyjskim literami. Przy Afrodycie widnieje podpis $\Gamma \wedge \triangle P E T A$, wymowa Pedrita ${ }^{211}$. Bogini Padrita/Pedrita nigdy nie stała się głównym bóstwem Ksanthos (bo ta rola przypadła trójcy z Delos: Apollonowi, Artemidzie i Latonie), ale czczono ją nadal, o czym świadczy inskrypcja z czasów rzymskich dedykowana „Afrodycie słuchającej” ('A $\dot{\varepsilon} \pi \eta \kappa o ́ \omega)^{212}$.

Aretologia (w. 2-11) odnosi się do wyjaśnienia symboliki świętego posągu, który został erygowany jeszcze $\mathrm{w}$ czasach pogańskich przez administrację miasta, nie wiadomo, jak dawno temu. W czasach klasycznych często wznoszono świątynie i posągi dla Afrodyty Pandemos („Ludowej”), patronki demokracji i magistratu ${ }^{213}$. Jednak przydomek „Pandemos” nie pada ani w tym hymnie, ani nigdzie indziej w pismach Proklosa. Pojawiają się za to dwa inne epitety bogini: Urania („Niebiańska”, w. 6) i Olympios („Olimpijska”, w. 7). Drugi przydomek pozwala pozycjonować tę boginię w dodekadzie hiper-enkosmicznej, zwanej olimpijską, w VI 11 (por. tabela 1). Afrodyta występuje tu w triadzie anagogicznej wraz z Hermesem i Apollonem, a jej mąż Hefajstos w wyższej triadzie stwórczej tego samego porządku ${ }^{214}$. Ta niższa Afrodyta była córką Dione, sprawowała pieczę nad małżeństwami ${ }^{215}$ i nosiła przydomek Pandemos ${ }^{216}$, czego Proklos nie chce otwarcie przyznać. Odnoszący się do niższej Afrodyty epitet „Urania” został może zaczerpnięty z Wyroczni chaldejskich ${ }^{217}$ albo należy go odczytywać w tym sensie, że bogini rządzi niebem i wiąże je w jedną całość z ziemiąą18.

Neoplatonicy żywo interesowali się kultem posągów. Rozróżniali mniej i bardziej święte wśród nich. Damascjusz pisze o specjalistach, którzy znali się na tym ${ }^{219}$. Opisany tutaj posąg trzyma w rękach święte symbole (tekst nie

${ }^{211}$ Por. G. Neumann, Neufunde lykischer Inschriften seit 1901, Wien 1979, Verlag der Österreichischen Akademie der Wissenschaften (Repr. z 1901), nr 307a; D.E. Strong, A Greek Silver Head-Vase, „The British Museum Quarterly” 28 (1964) 95-102.

${ }^{212}$ Por. Tituli Asiae Minoris II 1 nr 269, ed. E. Kalinka, Vienna 1920, Akademie der Wissenschaften in Wien.

${ }^{213}$ Por. Supplementum Epigraphicum Graecum (= SEG) XXVI 1039 - inskrypcja z Erytrai, ok. 400 prz. Chr.; F. Sokolowski, Aphrodite as Guardian of Greek Magistrates, HTR 57 (1964) 1-8 liczne świadectwa tego kultu w Atenach od okresu klasycznego.

${ }^{214}$ Por. Proclus, Theologia Platonica VI 22, ed. Saffrey - Westerink, VI 97, $15-17$ i 98, 18-19.

${ }^{215}$ Por. Plotinus, Enneades III 5, 2, 14-19, éd. Bréhier, III, s. 77.

${ }^{216}$ Por. Por. Plato, Symposium 181a.

${ }^{217}$ Por. OC 173, ed. Majercik, s. 112.

${ }^{218}$ Por. Proclus, In Platonis Cratylum commentaria 183, ed. Pasquali, 111, 9-11.

${ }^{219}$ Por. Damascius, Vita Isidori fr. 174, ed. Zintzen, s. 147: „Heraiskos miał wrodzony talent rozpoznawania świętych posągów: żywych i martwych. Gdy tylko spojrzał, jego serce przeszywał boski szał, zaś ciało i duszę ogarniały dreszcze, jakby był opętany. Jeśli nie zachowywał się w taki sposób, znaczyło to, że posąg jest bez życia i nie ma w nim boga. W ten sposób rozpoznał święty posąg Eona, którego Aleksandryjczycy czcili, jako owładnięty przez bogów Ozyrysa i Adonisa zgodnie z mistyczną zasadą teokrazji". 
podaje, jakie), które, jak pisze autor, mają związek z mistycznymi zaślubinami Afrodyty z Hefajstosem (w. 5). Gdzie indziej Proklos omawia i alegorycznie interpretuje znany mit o trójkącie małżeńskim Afrodyty, Hefajstosa i Aresa w tym sensie, że te demiurgiczne bóstwa stwarzają świat widzialny poniżej nich ${ }^{220}$. Nie wiadomo właściwie, dlaczego małżeństwo Afrodyty i Hefajstosa, nieudane i zakończone rozwodem, filozof uważa w tym miejscu za święte. Tam gdzie podaje przykłady świętych małżeństw, tj. Zeus i Hera, Okeanos i Gaia, Kronos i Rea, Zeus i Demeter, Zeus i Kora, nie wymienia Hefajstosa i Afrodyty ${ }^{221}$. Hymny orfickie wolą nie wypowiadać się na temat pożycia tej pary ${ }^{222}$, zaś literatura piękna zajmuje się raczej romansem Afrodyty z Aresem niż jej związkiem z kulawym mężem.

Posąg z okiem utkwionym w Cnotę (w. 9) może oznaczać, że statua znajdowała się w sanktuarium lub obok posągu Ateny, ponieważ Atena nosiła kultowe imię Arete, czyli Cnota 223 . Bogini Atena, szczególnie czczona w Licji, występuje w tamtejszych zabytkach ramię w ramię z Afrodytą. Najtrudniejsze do interpretacji i właściwie niezrozumiałe wedle naszego stanu wiedzy są w. 9-11. Mitologia nie zna żadnych dzieci Afrodyty i Hefajstosa. Możliwe, że autor odnosi się tu do Rapsodii orfickich. Pseudo-Klemens, który znał ten zaginiony poemat, pisał o małżeństwie Afrodyty z jakimś ognistym duchem Pneuma i wyjaśniał je fizykalnie jako zaślubiny ognia i wody ${ }^{224}$.

Modlitwa (w. 12-15) zawiera informację o licyjskim pochodzeniu Proklosa (w. 13), podobną do tej, którą filozof zamieścił we własnym epigramie nagrobnym $^{225}$. Ofiara, którą poeta składa ojczystej bogini - odśpiewanie hymnu (w. 12-13), jest jedyną, jaką wolno było zanosić niewidzialnym bogom (por. Wprowadzenie 2-3). Prośba o piękno duszy jest odpowiednia dla tej anagogicznej bogini (por. tabela 2).

\section{Hymn 6}

Hymn do Matki Bogów, Hekate i Janusa-Zeusa jest najbardziej chaldejski spośród Hymnów Proklosa i wyróżnia się nietypową kompozycją ${ }^{226}$. Albowiem inwokacja do triady bóstw, powtórzona słowo w słowo, otwiera i zamyka ten utwór (w. 1-3 = 13-15). Refren, rzecz niezwykła w antycznej poezji, wystąpił już w jednym z Hymnów metrycznych Synezjusza z Cyreny ${ }^{227}$, lecz nie two-

${ }^{220}$ Por. Proclus, In Platonis Rem publicam commentarii, ed. Kroll, I 141, 1 - 143, 16; tenże, In Platonis Timaeum commentaria, ed. Diehl, I 333, 2-4 i II 27, 16 - 28, 7; zob. Lankila, Aphrodite in Proclus'Theology, s. 32-34.

${ }^{221}$ Por. Proclus, In Platonis Parmenidem II 775, 20-36, ed. Steel, I, s. 184.

${ }^{222}$ Por. OH 55 Do Afrodyty i 66 Do Hefajstosa, ed. Ricciardelli, s. 144-146 i 170.

${ }^{223}$ Por. Proclus, In Timaeum Platonis commentaria, ed. Diehl, I 170, 3-10; OF 266.

${ }^{224}$ Por. Ps-Clemens, Homiliae VI 13, 2, GCS 42 bis, 111.

${ }^{225}$ Por. Marinus Neapolitanus, Vita Procli 36, ed. Masullo, s. 92: ,Ja jestem Proklos rodem z Licji”.

${ }^{226}$ Por. J. Danielewicz, Morfologia hymnu antycznego, Poznań 1976, UAM, 89.

${ }^{227}$ Por. Synesius Cyrensis, Hymnus 8(9), 10-11 = 28-29, éd. Lacombrade, s. 94-95. 
rzył ram kompozycyjnych jak tutaj. Uporczywa repetycja $\chi \alpha \hat{\imath} \rho \varepsilon$ (,witaj!’) na początku każdego $\mathrm{z}$ wersów i dwukrotna w trzecim przypomina hymny magiczne $^{228}$. Pomiędzy refrenami umieszczona została modlitwa (w. 4-12). Hymn 6 różni się od innych znanych hymnów do Matki Bogów: homeryckiego ${ }^{229}$, orfickiego ${ }^{230}$ i epigraficznego z Epidauros ${ }^{231}$.

Inwokacja (w. 1-3 = 13-15). Podstawowy problem, który nastręcza ten krótki tekst, to liczba bogów. Jedynym miejscem w systemie Proklosa, gdzie bóstwa te występują razem w sekwencji Matka Bogów (= Rea), Hekate i Zeus, jest IV 2-3 w tabeli 1. Jak widzimy, obie boginie są tu równorzędne, z tym, że Rea znajduje się po stronie orfickiej, a Hekate - chaldejskiej. W takim razie otrzymujemy dwa bóstwa, a nie trzy ${ }^{232}$. R. M. Van den Berg ${ }^{233}$ kontrargumentuje, że są tu jednak trzy bóstwa: Rea i jej syn Zeus - Umysł Demiurga (pozycja IV 2-3 w tabeli 1) oraz Artemida-Hekate, należąca do niższych demiurgów (pozycje V 4 i VI 9).

Moim zdaniem, identyfikacja bóstw powinna być jeszcze inna: Matka Bogów to Rea, żona Kronosa i macierz dwudziestu czterech bogów ${ }^{234}$; Hekate to chaldejskie alter ego Rei ${ }^{235}$; Janus nie jest identyczny z Zeusem, choć obaj znaleźli się razem w jednym wersie. Janus bowiem był utożsamiany nie z Zeusem, lecz z Kronosem ${ }^{236}$, a Zeus był uważany za syna jego i Rei. W systemie chaldejskim Hekate zajmowała pozycję centralną pomiędzy dwoma Ojcami Źródła, czyli właśnie Kronosem i Zeusem ${ }^{237}$. Proklos zatem adresuje Hymn 6 do trzech następujących bóstw: Rei-Hekate, Kronosa-Janusa i Zeusa, które razem stanowią pierwszą triadę noeryczną (IV 1-3 w tabeli 1).

Filozoficzna interpretacja Matki Bogów nie jest jedyną możliwą. Wiadomo od Marinosa, że pobożny Proklos czcił tę boginię w sposób szczególny,

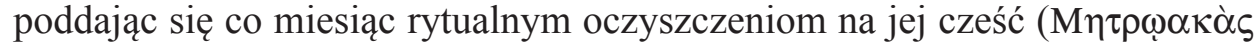
... א $\left.\alpha \sigma \tau \varepsilon^{\prime} \alpha \varsigma\right)$, jak dawniej Frygowie i Rzymianie, i otrzymał od niej wiele

${ }^{228}$ Por. PGM IV 670-672b, 688-692.

${ }^{229}$ Por. Hymni Homerici 14.

${ }^{230}$ Por. OH 27 Do Matki Bogów, ed. Ricciardelli, s. 76.

${ }^{231}$ Tekst wydawany wielokrotnie, m.in. w IG IV 1 1, 131; SEG LV 426; Greek Hymns: Selected Cult Songs from the Archaic to the Hellenistic Period, ed. W.D. Furley - J.M. Bremer, I, Tübingen 2001, Mohr, 214-223.

${ }^{232}$ Por. Lewy, Chaldean Oracles and Theurgy, s. 365-366.

${ }^{233}$ Por. Van den Berg, Proclus' Hymns, s. 256-262.

${ }^{234}$ Por. Proclus, Theologia Platonica V 11, ed. Saffrey - Westerink, V 35, 21 - 39, 24; tenże, In Platonis Timaeum commentaria, ed. Diehl, III 179, 9-10.

${ }^{235}$ Jeden z fragmentów Wyroczni chaldejskich nazywa Hekate Reą, por. OC 56, ed. Majercik, s. 70: „Rea - źródło i zdrój noerycznych bogów. Ona pierwsza w swym tajemnym łonie przyjmuje narodziny ich wszystkich i pospiesznie rozlewa na wszechświat".

${ }^{236}$ Por. Herodianus, Ab excessu divi Marci I 16, 1-2, ed. E. Bekker, Leipzig 1855, Teubner, 31.

${ }^{237}$ Por. OC 50, ed. Majercik, s. 68; Proclus, Theologia Platonica V 11, ed. Saffrey - Westerink, V 36-37. 


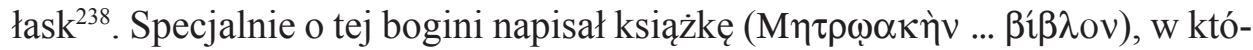
rej wyjaśniał alegorycznie misteria, mity i pieśni lamentacyjne śpiewane o niej i Attysie ${ }^{239}$. Biograf zachęca do przeczytania tej książki. W domu należącym przypuszczalnie do Proklosa i odkopanym pod Akropolem archeologowie znaleźli kapliczkę z wizerunkiem Matki Bogów, a także kości prosiąt, które były tam składane w ofierze ${ }^{240}$.

Marinos opowiada o pewnym epizodzie z życia swego mistrza, kiedy musiał zawiesić działalność Akademii na rok (data nieustalona). Wtedy to wyjechał na głęboką prowincję, do Lidii w Azji Mniejszej, by tam poświęcić się bez reszty badaniu tajemnych misteriów, które przetrwały w ludzkiej pamięci ${ }^{241}$. Informacja ta odnosi się zapewne do lidyjskich rytuałów na cześć Matki Bogów. Pauzaniasz Periegeta w II wieku po Chr. odwiedził świątynię i posąg Matki Plastene na górze Sipylos koło Magnezji w Lidii ${ }^{242}$, te same, które zostały odkopane w 1887 $\mathrm{roku}^{243}$. Znaleziono tam greckie inskrypcje: fundacyjną ${ }^{244} \mathrm{i}$ dwie dedykacyjne z imieniem Matki Bogów Plastene ${ }^{245}$, marmurowy relief z wyobrażeniem samej bogini z jej atrybutami, paterą i tympanonem ${ }^{246}$ oraz marmurowy posąg Plastene siedzącej między lwami ${ }^{247}$. Zabytki te pochodzą z wieków od II do IV.

Zestawienie Matki Bogów z Hekate i Janusem nie było niezwykłe w religii późnoantycznej. Znane są reliefy z przedstawieniami tronującej Matki Bogów adorowanej przez Hekate z pochodnią i Hermesa Kadmilosa ${ }^{248}$. Zdarzało się połączenie Matki Bogów z Janusem, czyli jej mężem Saturnem²49.

${ }^{238}$ Por. Marinus Neapolitanus, Vita Procli 19, ed. Masullo, s. 75.

${ }^{239}$ Por. tamże 33, ed. Masullo, s. 90 = Suda, Lexicon Pi 2473, ed. Adler, s.v. Proclus.

${ }^{240}$ Por. A. Karivieri, The „House of Proclus” on the Southern Slope of the Acropolis: A Contribution, w: Post-Herulian Athens: Aspects of Life and Culture in Athens A.D. 267-529, ed. P. Castrén, Helsinki 1994, Suomen Ateenan-instituutin, 115-139.

${ }^{241}$ Por. Marinus Neapolitanus, Vita Procli 15, ed. Masullo, s. 71-72: „Wyjechał wtedy z Aten i odbył podróż do Azji, uznawszy, że dobrze mu to zrobi. Mówią, że do tego wyjazdu zachęcił go jego duch opiekuńczy (daimonion), aby zapoznał się z dawnymi rytuałami, które tam jeszcze się zachowały. On sam coraz lepiej rozumiał tamtejsze rytuały, zaś miejscowi uczyli się od niego, filozofa, sensu czynności rytualnych, które od długiego czasu zaniedbali. Tak czyniąc, tak żyjąc, zrealizował lepiej niż pitagorejczycy zalecenie ich mistrza ŻYJ W UKRYCIU. Po rocznym pobycie w Lidii powrócił do Aten, wiedziony przez opatrzność bogini, która miłuje mądrość".

${ }^{242}$ Por. Pausanias, Graeciae descriptio III 22, 4, ed. M.H. Rocha-Pereira, I-III, Leipzig 19731981, Teubner, tutaj I, s. 258; tamże V 13, 7, ed. Rocha-Pereira, II, s. 32.

${ }^{243}$ Por. Corpus Cultus Cybelae Attidisque (= CCCA), ed. M.J. Vermaseren, I-VII, Leiden $1977-$ 1989, Brill, tutaj CCCA I 443.

${ }^{244}$ Por. CCCA I 451.

${ }^{245}$ Por. CCCA I 452-452.

${ }^{246}$ Por. CCCA I 450.

${ }^{247}$ Por. CCCA I 452; zob. także Lexicon iconographicum mythologiae classicae (= LIMC), ed. H.C. Ackermann et al., I-XX, Zürich 1981-2009, Artemis, tutaj LIMC VIII/1 749, s.v. Kybele.

${ }^{248}$ Por. CCCA V 28; relief z Berlina SK 691/K 106.

${ }^{249}$ Por. inskrypcja wotywna z Maktar: CCCA V 78: MATRI MAGNAE ET IANO PATRI AUGUSTO. 
Autorzy antyczni lubili wydobywać analogie między grecką boginią Hekate a rzymskim bogiem Janusem: oba bóstwa strzegły drzwi, dlatego też dzieliły kultowy przydomek „odźwierny” ( $\theta$ vpoîs), i miały dwie twarze, po jednej z przodu i z tyłu głowy, skąd wziął się ich wspólny epitet „o dwu twarzach”

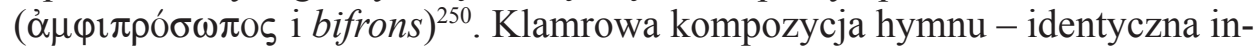
wokacja na początku i na końcu - stanowi ilustrację tego właśnie przydomka.

Modlitwa (w. 4-12) maluje obraz rozbitka, który błąka się po dalekich morzach w ciemności i obłędzie, nie mogąc odnaleźć drogi do domu. Obraz jest oczywiście alegoryczny: marynarz to dusza ludzka, zmuszona do wcielenia się, fale morskie to wody kolejnych narodzin, niebieskie jak niesamowita bogini inkarnacji Nemezis z pieśni Mezomedesa ${ }^{251}$. W krótkim tekście modlitwy powtarza się zdanie: „Tak, błagam, rękę podajcie” (w. 8 i 11), które jest ewidentnym odniesieniem do teurgii ${ }^{252}$. Zły stan zachowania Wyroczni chaldejskich nie pozwala doprecyzować, w jakim momencie rytuału i kogo z bogów teurg prosił o podanie pomocnej dłoni. Synezjusz z Cyreny w jednym z hymnów także błagał Boga o podanie ręki i uwolnienie z kajdan życia i ciała, ziemi i materii. Ustęp z Synezjusza, żywo przypomina treść i kontekst modlitwy Proklosa:

„Ciało moje zachowaj

Wolne od chorób,

Ducha mojego zachowaj

Wolnego od hańby!

Przynieś mej duszy

Zapomnienie o żądzach,

Aby skrzydło duszy

Utuczyło się

W tym życiu,

Tu na ziemi,

Na Twoich hymnach.

Abym po tym życiu,

Życiu w ciężkich

Kajdanach ziemskich,

Wolny od materii,

Wzleciał prosto

${ }^{250}$ Por. Macrobius, Saturnalia I 9, 4-13, ed. Kaster, I, s. 92 (Janus i Hekate jako odźwierni; Janus bifrons i Janus quadriformis); Plutarchus Chaeronensis, Numa 19, 6 (Janus); Proclus, In Timaeum Platonis commentaria, ed. Diehl, II 130, 23; II 246, 19 (Hekate u Proklosa ma dwie twarze, bo patrzy na bogów ponad nią i jednocześnie na bóstwa niższe, których jest matką, w tym na Duszę Świata); LIMC V/1 618-623, s.v. Ianus (przedstawienia ikonograficzne dwugłowego Janusa).

${ }^{251}$ Por. Mesomedes, Fragmenta, DAGM 28: „O Nemezis, skrzydlata szalo życia, niebieska bogini, córko Dike!”. Nemezis była często wyobrażana w sztuce jako niebieski gryf, który obraca koło losu, por. fajansowa figurka z Egiptu z II wieku, Brooklyn Museum nr inv. 53.173.

${ }^{252}$ Por. OC 210c, ed. Majercik, s. 128: „synowie teurgów nazywają demiurgiczne moce rękami”. 
Na twój dwór,

Do twego łona,

Skąd duszy

Wylewa się źródło.

Ty rękę podaj,

Ty wezwij, ty szczęśliwy,

Z materii wyprowadź

Błagalną duszę" 253.

Uwolnienie się z więzów życia to tylko wstępna prośba. Tą właściwą i najważniejszą jest szczęśliwy powrót do Boga - do portu pobożności u Proklosa (Hymn 6, w. 12), na łono i dwór Ojca u Synezjusza. Powrót do portu i światła to również temat chaldejski ${ }^{254}$. Proklos uwielbia rozpisywać się o ziemskiej odysei duszy, która po długich wędrówkach w ciele zawija wreszcie do ,mistycz-

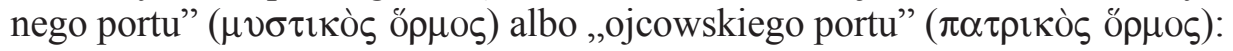

„Jedynie życie zgodne z Umysłem jest wolne od tułaczki i to jest właśnie ów mistyczny port duszy, do którego poezja przyprowadza Odyseusza ${ }^{255}$ po wielu tułaczkach życia" ${ }^{256}$.

„Po wędrówkach w świecie narodzin, po oczyszczeniu, po świetle wiedzy oświeca nas wreszcie noeryczna aktywność - umysł w nas, który kotwiczy duszę w Ojcu, wpaja w nią demiurgiczne intelekcje, stapia się jak światło ze światłem - światło piękniejsze, subtelniejsze i prostsze niź światło wiedzy. To jest właśnie ojcowski port, znajdowanie Ojca, nieskalane zjednoczenie z Nim"257.

W systemie Proklosa Ojciec, do którego dusza wraca po ziemskich wędrówkach, to Zeus, drugi Ojciec Źródła, Umysł Demiurga i pierworodny syn Matki Bogów (por. IV 3 w tabeli 1), odpowiedzialny za ع̇ szych bogów i dusz do Ojca i Bytu, z którego wszyscy emanowali (por. I-II w tabeli 1$)^{258}$. Umysł człowieka, co prawda, identyfikuje się z Umysłem Boskim,

${ }^{253}$ Synesius Cyrensis, Hymnus 2(4), 275-299, éd. Lacombrade, s. 66.

${ }^{254}$ Por. OC 115, ed. Majercik, s. 92: „Trzeba się spieszyć do światła i do promieni Ojca, skąd została wysłana twoja dusza, odziana w wielki intelekt”. „Port” jest to przypuszczalnie termin chaldejski, jednak w zachowanych fragmentach Wyroczni chaldejskich brak tego wyrażenia.

${ }^{255}$ Alegoryczna interpretacja Odysei - jako przygody duszy w morzu materii - była pomysłem wcześniejszych neoplatoników, zob. Plotinus, Enneades I 6, 8, 12-21, éd. Bréhier, I, s. 104, thum. pol. Krokiewicz, I, s. 139; Porphyrius, De antro nympharum 34-35, ed. Simonini, s. 80-84, thum. P. Ashwin-Siejkowski: Porfiriusz z Tyru, Grota Nimf, ŹMF, Kraków 2006, WAM, 77-79 (Porfiriusz cytuje tu medioplatonika Numeniusza z Apamei, fr. 33, éd. É. des Places, Paris 1973, Les Belles Lettres, 84).

${ }^{256}$ Proclus, In Platonis Parmenidem V 1025, 25-27, ed. Steel, II, s. 255.

257 Proclus, In Platonis Timaeum commentaria, ed. Diehl, I 302, 17-25; por. tenże Theologia Platonica IV 26, ed. Saffrey - Westerink, IV 77, 20-21.

${ }^{258}$ Por. Van den Berg, Proclus' Hymns, s. 51-56. 
ale powrót do owego upragnionego światła wymaga oczyszczenia się z całego brudu życia ziemskiego i dlatego nie jest łatwy. Stąd autor, Odyseusz na morzu materii, modli się do bóstw o dwu twarzach o zesłanie pomyślnych wiatrów.

\section{Hymn 7}

Hymn do Ateny jest najdłuższym (w. 1-52) i najbardziej osobistym (obok Hутпи 5) z zachowanych Hymnów Proklosa oraz jedynym, który zawiera treść mitologiczną w aretologii. Obsesyjnie powtarzane „słuchaj!” ( $\kappa \lambda \hat{v} \theta \mathrm{v} /$ $\kappa \varepsilon ́ \kappa \lambda v \theta \imath$ ) ma przykuć uwagę adresatki do błagalnej postawy piszącego, który znalazł się w szczególnie trudnej sytuacji życiowej, jak również stanowić nawiązanie do Hymnów orfickich, gdzie słowo to jest nadużywane ${ }^{259}$. Hymn dzieli się na inwokację, aretologię i rozbudowaną część prekacyjną. Utwór zdecydowanie różni się od dwu hymnów homeryckich do Ateny ${ }^{260}$, mimo homeryckich fraz, którymi operuje $\mathrm{e}^{261}$, i od krótkiego hymnu orfickiego do Ateny $^{262}$, który miał być śpiewany podczas ofiary z wonnego kadzidła. Być może Hymn 7 wykazywałby więcej analogii do peanu z Epidauros (III wiek po Chr.), gdyby ten ostatni zachował się w lepszym stanie 263 .

Inwokacja (w. 1-6) zawiera wystarczająco wiele wskazówek, by można było zidentyfikować właściwą Atenę w tabeli 1, gdzie bogini ta pojawia się trzykrotnie na różnych poziomach boskości (w IV 4, V 6 i VI 5). Atena, jak czytamy w hymnie (w. 1-2), ma emanować (w tekście greckim orficko-chaldejskie słowo „wytryskać”264) bezpośrednio ze źródła swego ojca Zeusa i jest pierwsza w łańcuchu; musi więc chodzić o lokalizację w IV 6. Atena emanowała dalej, jak pisze Proklos w innym miejscu ${ }^{265}$, na bogów drugo- i trzeciorzędnych, stąd jej dwukrotna obecność w Berle Fanesa (V 6 i VI 5) i kultowy przydomek „Tritogeneia” (por. w. 3) - bo Proklos wyprowadza etymologię tego epitetu od $\tau \rho i ́ \tau o \varsigma$, czyli „trzeci”, „trzeciorzędny”. Nie można uważać owej Pallady Tritogenei (jak Van den Berg ${ }^{266}$ ) za boginię należącą do archontów, gdyż w tym miejscu (V 6) występuje ona w triadzie ożywicieli wraz z Artemidą i Korą i nie jest pierwsza w łańcuchu, lecz ostatnia ${ }^{267}$. Atena z Hymnu 7 rozpoczyna drugą

${ }^{259}$ Por. OH 3, 3; 4, 9; 8, 1 i 20; 9, 1 i inne.

${ }^{260}$ Por. Hymni Homerici 11 i 28.

${ }^{261}$ Por. Van den Berg, Proclus' Hymns, s. 274-314.

${ }^{262}$ Por. OH 32, ed. Ricciardelli, s. 88-90.

${ }^{263}$ Hymn IG IV² 1, 134 zaczyna się od adnotacji, że ma być śpiewany o trzeciej godzinie, czyli o dziewiątej rano. Czytelne są początki dwóch pierwszych wersów: „Witaj Pani Pallado..., wspaniała dziewico...”. Ułamki dalszych słów pozwalają wnosić, że opiewa się Atenę w zbroi i takiej postaci, jaką nadał jest Fidiasz w posągu chryzelefantynowym stojącym w Partenonie na Akropolu. Rekonstrukcja i fotografia utworu, w: R. Wagman, Restorations on the Epidaurian Hymns, ZPE 103 (1994) 101-102.

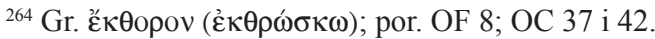

${ }^{265}$ Por. Proclus, In Platonis Timaeum commentaria, ed. Diehl, I 166, 25-27.

${ }^{266}$ Por. Van den Berg, Proclus' Hymns, s. 40.

${ }^{267}$ Por. Theologia Platonica VI 11, ed. Saffrey - Westerink, VI 51, 20 - 52, 5. 
triadę noeryczną - triadę Nieskalanych (IV 4-6), która wraz z pierwszą triadą noeryczną (IV 1-3) i monadą podziału (IV 7) tworzy noeryczną hebdomadę, czyli Umysł Demiurga (IV). Z tego właśnie powodu w drugiej części hymnu pojawiają się określenia Ateny takie jak „mądrość” (w. 7) i ,noeryczna sztuka" (w. 20). W podobnym sensie i miejscu w hierarchii bogini ta wystąiła w systemie teozoficznym Juliana Apostaty, gdzie była nie tylko pierwszym demiurgiem, umysłem Heliosa ${ }^{268}$, lecz także osobistą strażniczką cesarza, która wyrwała go z rąk morderczych krewnych i pomogła zdobyć tron ${ }^{269}$.

Aretologia (w. 7-30) odnosi się do pięciu następujących mitów:

1 skądinąd nieznanej wersji gigantomachii (w. 7-8);

2 orfickiego mitu o nieudanych zalotach Hefajstosa do Ateny (w. 9-10) ${ }^{270}$;

3 kolejnego orfickiego mitu o ocaleniu przez Atenę bijącego serca Bachusa, Duszy Świata (por. VII 1b w tabeli 1), którego poćwiartowali Tytani (w. 11-15) ${ }^{271}$;

4 nieznanego mitu o walce Ateny z Hekate (w. 16-20);

5 znanej opowieści o tym, jak Atena i Posejdon rywalizowali o Akropol (w. 21-30) ${ }^{272}$.

Być może mit o Atenie i Hekate („Tyś to toporem swoim wykarczowała bydlęce łby żądz wszystkowidzącej Hekate") ma jakiś związek z chaldejskimi psami. Wyrocznie Chaldejskie mówią o demonicznych psach, względnie bestiach, które Hekate trzyma pod kluczem w głębinach ziemi i jeździ na nich, kiedy zechce. Również Synezjusz z Cyreny obawia się szczeniąt, pożeraczy dusz, które zsyła skrzydlaty demon materiii ${ }^{273}$. Bez względu na to, czy bestie Hekate są chaldejskie, czy nie, należy je lokalizować w VII 5b w tabeli 1.

\footnotetext{
${ }^{268}$ Por. Julianus, Oratio IV(XI) 31-32, 149a-150a i 40, 154d.

${ }^{269}$ Por. tenże, Oratio VII 22, 232c-234a.

${ }^{270}$ Por. OF 270.

${ }^{271}$ Por. OF 326-329; Proclus, In Platonis Timaeum commentaria, ed. Diehl, II 173, 1-7; tenże In Platonis Alcibiadem, ed. A.P. Segonds: Sur le „Premier Alcibiade” de Platon, I, Paris, 1985, Les Belles Lettres, 43, 24.

${ }^{272}$ Por. Apollodorus, Bibliotheca III 14, 1; Proclus, In Platonis Timaeum commentaria, ed. Diehl, I 173, 9-15.

${ }^{273}$ Por. OC 90, ed. Majercik, s. 84: „Z łona ziemi wyskakują chtoniczne psy. Nigdy nie pokazują śmiertelnym żadnego prawdziwego znaku”; tamże 91, ed. Majercik, s. 84: „powozi powietrznymi, ziemskimi i wodnymi psami”; tamże 135, ed. Majercik, s. 100: „Nie wolno ci patrzeć na owe psy przed inicjacją w ciele. Bo te psy są chtoniczne, złośliwe i bezwstydne, czarują dusze i odwodzą je od inicjacji”; tamże 157, ed. Majercik, s. 108: „W twym naczyniu zamieszkają bestie ziemi”; Synesius Cyrensis, Hymnus 1(3), 88-101, éd. Lacombrade, s. 48: „Niech się schowa pod ziemię skrzydlaty wąż - demon materii, chmura dusz, miłośnik idoli, co podczas modlitw szczeniaki woła. Ty Ojcze, Ty szczęśliwy, Ty odpędź psy - pożeraczy serc od mej duszy, od moich modłów, od mego życia, od moich spraw”; tenże, Hymnus 2(4), 241-256, éd. Lacombrade, s. 66: „Odpędź choroby, odpędź troski, które niszczą duszę, odpędź bezwstydnego psa podziemnego, demona ziemi od mojej duszy, od moich modłów, od mego życia, od moich spraw! $Z$ dala od ciała, z dala od ducha, z dala od wszystkich naszych spraw niech demon czeka!"; zob. S.I. Johnston, Hekate Soteira: A Study of Hecate's Roles in the Chaldean Oracles and Related Literature, Atlanta GA 1990, Scholar, 134-142.
} 
Modlitwa (w. 31-52) wnosi osobisty akcent. Atena, opiewana przez Rap-

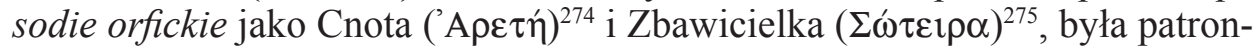
ką Proklosa od chwili narodzin, stąd jego deklaracja ,jestem twój” (w. 42). Marinos informuje, że Atena Poliuchos, protektorka Konstantynopola, asystowała matce Proklosa przy porodzie, a potem, gdy dorósł, ukazała mu się we śnie, nakazując studiowanie filozofii. To ona zachęciła go, by rzucił studia retoryczne w Aleksandrii i zajął się filozofią perypatetycką, a następnie wstąpił do Akademii Platońskiej (w 430 r.) ${ }^{276}$. Gdy został diadochem Akademii (w 437 r.), zamieszkał u stóp Akropolu w tym samym domu, który należał ongiś do Plutarcha i Syrianosa (dom ten został odkopany, zob. Karivieri). Posesja znajdowała się między świątynią Asklepiosa a teatrem Dionizosa, więc okna Akademii wychodziły na Akropol - symbol Ateny ${ }^{277}$ (por. Hymn 7, w. 22).

W 470 r., gdy filozof miał 58 lat, posąg Ateny Dziewicy dhuta Fidiasza został usunięty z Partenonu przez „świętokradców”, przez których Marinos rozumie chrześcijan. Był to ciężki cios dla Proklosa. Bogini zesłała mu wtedy pocieszający sen, zapowiadając, że wkrótce przeprowadzi się do niego ${ }^{278}$. Biograf pisze o ,przeciwnych wiatrach Tyfona” i ,gryfogigantach”, czyli znowu chrześcijanach, którzy rozpętali taką nagonkę na filozofa (data nie jest możliwa do ustalenia), iż musiał opuścić swój dom u stóp Akropolu i udać się na roczne wygnanie do Lidii ${ }^{279}$. Zapewne w tych dramatycznych okolicznościach powstała polemika pt. Osiemnaście dowodów antychrześcijańskich ${ }^{280}$ i być może hymn do Ateny. Wtedy zrozumiała się staje tak żarliwa modlitwa o obronę przed wrogami (Hymn 7, w. 52). Być może „Giganci” z w. 8, których Atena pokonała swą mądrością, to także chrześcijanie, ponieważ w kręgu Akademii Platońskiej miano to było zastrzeżone dla chrześcijan. Przezwisko wzięło się stąd, że za chrześcijańskiego władcy Teodozjusza II wzniesiono na

${ }^{274}$ Por. OF 266.

${ }^{275}$ Por. OF 316.

${ }^{276}$ Por. Marinus Neapolitanus, Vita Procli 6 i 9, ed. Masullo, s. 63 i 65.

${ }^{277}$ Por. tamże 29, ed. Masullo, s. 86: „Pomagał mu w tym [tj. ŻYJ W UKRYCIU] także i dom, w którym zamieszkał. Miał bowiem szczęście mieszkać w tym samym dogodnym domu, gdzie uprzednio Syrianos, którego nazywał swoim ojcem, jak i Plutarch, którego nazywał dziadkiem. Dom ten znajdował się w bliskim sąsiedztwie świątyni Asklepiosa, deifikowanego przez Sofoklesa, i świątyni Dionizosa obok teatru, a także miał widok na Akropol".

${ }^{278}$ Por. Marinus Neapolitanus, Vita Procli 30, ed. Masullo, s. 86-87: „Przez wybór filozoficznego życia stał się drogi bogini miłującej mądrość. Sama to objawiła, gdy jej posąg wzniesiony w Partenonie został przeniesiony przez owych ludzi, którzy nie wahają się tknąć nietykalnych rzeczy. Filozofowi przyśniło się, że przyszła do niego piękna kobieta, która zapowiedziała, że musi szybko przygotować swój dom, bo pani Atenais pragnie z toba zamieszkać”.

${ }^{279}$ Por. tamże 15, ed. Masullo, s. 71: „Odwagę cywilną Proklos osiągnął w takim stopniu jak Herakles. Pośród największej zawieruchy, pośród sztormu i nawałnicy, gdy wiejące w oczy wiatry Tyfona wstrząsnęły jego uładzonym życiem, zdołał uratować się, wykazując się przy tym wielką odwagą i opanowaniem mimo niebezpieczeństwa. Niestety, pewnego razu stał się obiektem ataków pewnych gryfogigantów. Wtedy to, osaczony przez nich, musiał poddać się obrotowi wszechświata”.

${ }^{280}$ Por. Suda, Lexicon Pi 2473, ed. Adler, s.v. Proclus. 
ateńskiej agorze ogromny Pałac Gigantów (dat. 410-425), na który wychodziły okna domu Plutarcha, Syrianosa i Proklosa ${ }^{281}$.

Dziwić może suplikacja o żonę i dzieci u człowieka, który wyrzekł się małżeństwa, mimo że ukochany mistrz Syrianos pragnął ożenić go ze swą krewną Edezją 282 . Natomiast nie dziwi błaganie o sławę (w. 50), ponieważ Proklos był bardzo ambitny ${ }^{283}$, ani o zdrowie (w. 43-46), gdyż filozof obawiał się, że odziedziczył artretyzm po swym ojcu ${ }^{284}$. Atena należała do bóstw uzdrowicie$1 i^{285}$, tak jak Asklepios i Telesforos, u których filozof szukał ratunku, ilekroć źle się czu²86. Oblicze roztaczające święty blask (w. 31) to tyleż odniesienie do chryzelefantynowego posągu, który chrześcijanie usunęli z Partenonu, co standardowa cecha bóstw przynoszących zdrowie ${ }^{287}$.

\section{$* * *$}

Pytanie o to, do jakiej religii przynależą bogowie Hymnów wydaje się źle postawione. Proklos dążył do uzgodnienia różnych systemów religijnych między sobą i włączenia ich wszystkich w jeden wielki łańcuch bytów (por. tabela 1: Boska hierarchia Proklosa). Tendencja do łączenia a nie dzielenia różnych religii jest najlepiej widoczna w Hymnie 6, skomponowanym w taki sposób, że nie sposób rozstrzygnąć, czy treść odnosi się do wierzeń greckich, rzymskich czy chaldejskich. Badanie tożsamości religijnej bóstw Hymnów z pewnością sprzeciwiałoby się intencjom ich Autora.

Natomiast można i trzeba pytać, jaką część wielkiego łańcucha stanowią boscy adresaci Hymnów. Okazuje się, że są nimi Demiurgowie (por. pozycje IV-VI w tabeli 1). Autor nie zwraca się ani do Niewidzialnego Ojca, jak Synezjusz w swoich Hymnach, ani też do bogów kosmicznych, jak Hymny orfickie. Modlitwy swoje kieruje do bóstw, które, znajdując się pomiędzy dwoma sferami, niewidzialną i widzialną, odpowiadają zarówno za wcielenie dusz, jak i za tzw. $\dot{\varepsilon} \pi \iota \tau \rho \circ \varphi \eta ́$, czyli ich nawrócenie, naprawę i powrót do Jedna (por. I-II w tabeli 1). Właśnie powrót do Ojca, Pierwszego Ognia, wydaje się faktycznym - choć niewypowiedzianym - pragnieniem autora, który we wszystkich swych hym-

${ }^{281}$ Por. Athanassiadi, Persecution and Response in Late Paganism, s. 7.

${ }^{282}$ Por. Marinus Neapolitanus, Vita Procli 17, ed. Masullo, s. 73; Damascius, Vita Isidori fr. 124, ed. Zintzen, s. 105.

${ }^{283}$ Por. Marinus Neapolitanus, Vita Procli 32, ed. Masullo, s. 89; zob. też tamże 16, ed. Masullo, s. $72-73$.

${ }^{284}$ Por. tamże 31, ed. Masullo, s. 87.

${ }^{285}$ Por. Plutarchus Chaeronensis, Pericles 13.8 (kult Ateny Hygiei w Partenonie); Aelius Aristides, Hieroi logoi II 41-42, ed. Keil, s. 403-404 (Atena Dziewica z Partenonu ukazuje się we śnie podczas zarazy w $163 \mathrm{r}$. po Chr. i uzdrawia chorego).

${ }^{286}$ Por. Marinus Neapolitanus, Vita Procli 7 i 32, ed. Masullo, s. 64 i 88.

${ }^{287}$ Por. Hymn do Telesforosa, IG III ${ }^{1}$ 171, 15-16: „Ty swym obliczem rozpromienionym świętą radością budzisz śmiech wokół". Tekst pochodzi z ateńskiej inskrypcji, datowanej na II-III w. po Chr., zob. Furley - Bremer, Selected Cult Songs, I, s. 268-271. 
nach (z wyjątkiem Hymnu 5) modli się żarliwie o ratunek, niczym rozbitek na morzu narodzin. Można zaryzykować hipotezę, że hymny były częścią licznych rytuałów oczyszczających, którym poddawał się Proklos, by raz na zawsze stopić się z Ogniem i nigdy więcej nie wracać na ten świat: zimny, ciemny i głośny.

Przedstawiona w artykule analiza Hymnów 1-7 daje podstawę do identyfikacji bóstw i ułożenia Hymnów Proklosa w kolejności odpowiadającej pozycji hierarchicznej adresatów. Podaję od najwyższej do najniższej:

Hymn 6 hymn do Ojców Źródła, czyli Wielkich Demiurgów: Kronosa, Hekate i Zeusa

Hymn 7 hymn do Ateny, pierworodnej Zeusa Demiurga z Hymnu 6

Hymn 2 hymn do Afrodyty Uranii, ostatniej z Wielkich Demiurgów

Hymn 1 hymn do Heliosa, jednego z Demiurgów Niższych w tzw. Berle Fanesa

Hymn 4 hymn do triady anagogicznej olimpijskiej dwunastki w Berle Fanesa

Hymn 5 hymn do Afrodyty Dionaia, drugiej z tejże triady anagogicznej (por. Hymn 4)

Hymn 3 hymn do Muz, ostatnich Niższych Demiurgów z Berła Fanesa. Patrząc na gigantycznie rozbudowaną „boską hierarchię Proklosa” (tabela 1), nie powinniśmy tracić z oczu rzeczy najważniejszej: neoplatoński politeizm jest w swej istocie monoteizmem, bo ,jedność w tajemny sposób staje się wielością, a potem znowu jednością".

\section{PROCLUS' HYMNS: PHILOSOPHY AND CULTS}

\section{(Summary)}

The present paper consists of the introduction to the Neoplatonic and Chaldean systems, the first Polish translation of seven extant Hymns by Proclus (AD 412485), and the commentaries on each of them. This essay is a polemic against the well-known book by R.M. Van den Berg entitled Proclus' Hymns (Leiden 2001, Brill), which shows, above all, the Chaldean influences (cf. The Chaldean Oracles, ed. R. Majercik, Leiden 1989, Brill). I has argued that the philosopher used much more literary patterns than the Chaldean Oracles to illustrate the Neoplatonic „oecumenism" (an expression of P. Athanassiadi), i.e. syncretism of all the late-pagan religions. I has argued, further, that the philosopher's cult-songs had been used in purifications and mystery rites of all the religions, but there is no evidence for the theurgy alone. I disagree with M. Van den Berg in the main thesis of his book that the gods to whom the hymns were adressed should be identified with the leader-gods of Proclus' system. My argumentation leads to the conclusion that the gods of Proclus' Hymns can be identified with the Great Demiurges (Hymns 2, 6, 7) and the Lesser Demiurges (Hymns 1, 3, 4, 5). The elaborate theological system con- 
structed by Proclus and the location of gods from the Hymns in it are shown in the special diagram (table 1).

Slowa kluczowe: Proklos, hymny, system neoplatoniczny

Key words: Proclus, hymns, neoplatonic system 